\title{
دور البرامج التدريبية في رفع مستوى الكفايات المهنية لمعلي المرحلة الابتدائية، من وجهة نظر المعلمين بمدينة الطائف
}

\author{
إعداد \\ مطلق بن سعد أحمد البرلق . \\ باحث ماجستير أصول التربية \\ كلية التربية - جامعة الطائف.
}

Doi: 10.12816/0052740

مجلة الدراسات التربوية والانسانية ـ كلية التربية ـ جامعة دمنهور .

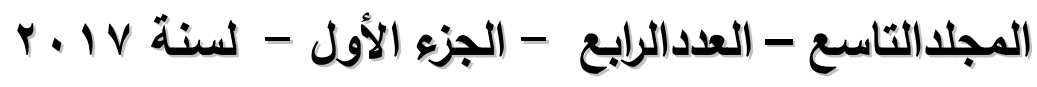


دور البرامج التدريبية في رفع مستوى الكفايات المهنية أ. مطلق بن سعد أحمد البرلق . 
دور البرامج التريبية في رفع مستوى الكفايات المهنية لمعلمي المرحلة الابتدائية، من وجهة نظر المعلمين بمدينة الطائف في مئف

أ. مطلق بن سعد أحمد البراق بمدانق

\section{Doi: 10.12816/0052740}

الملخص

تتاولت ابحث الحالى العلاقة بين البرامج التددريبية وأثرها فى رفع الكفايات

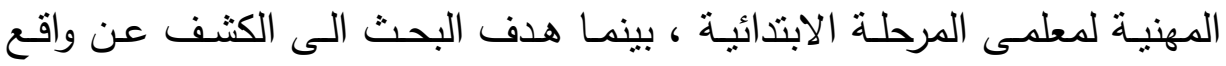

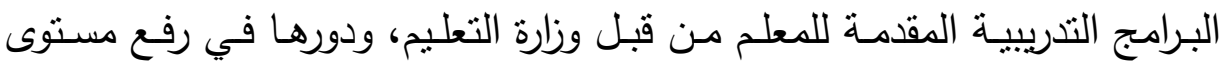

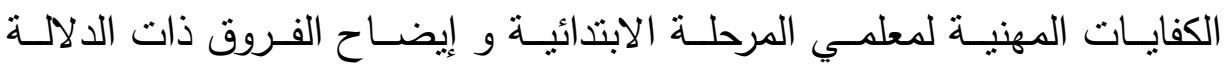

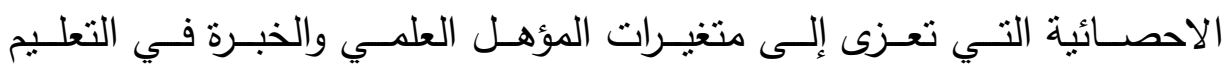
والتخصص.معتمداً على المنهج الوصفي والذي يعنى بجمع البيانات والمعلومات

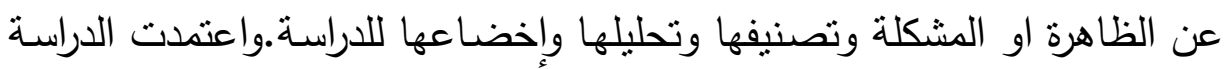
على عينة من (Y/I) معلماً من المرحلة الابتدائية بمدينة الطائف، وتم اختيارهم بالطريقة الطبقية العشوائية، وقام الباحث بتطوير استبانة كأداة لجمع المعلومات.

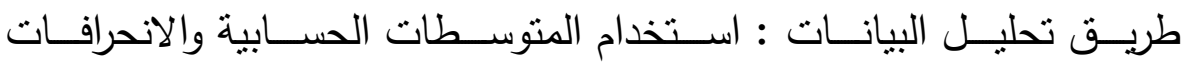
المعياريةواستخدام قيمة ( ف ) وتحليل التباين الأحادي ( one way Anova) وتوصلت الدراسة الى مجموعه نتائج أهمها وجود فروق ذات دلائلة الحئة إحصائية

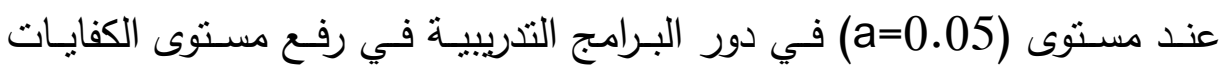

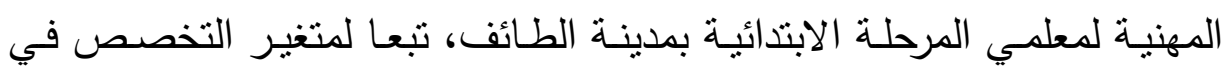

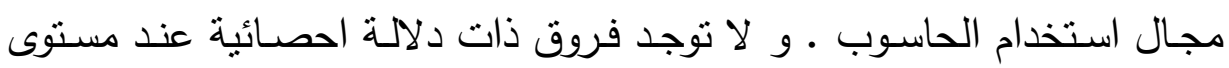

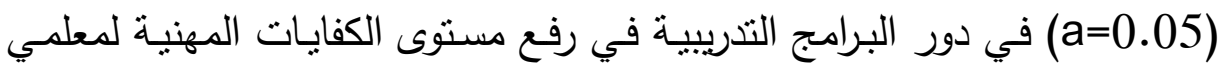

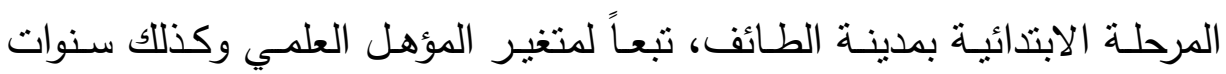
الخبرة.

الكلمات المفتاحية :البرامج التدريبية ـ الكفايات المهنية ـ المرحلة الابتدائية 


\section{المقدمة :}

تعدُ مهنة التعليم من المهن الصعبة التي تحتاج إلى إعداد جيد في المرحلة

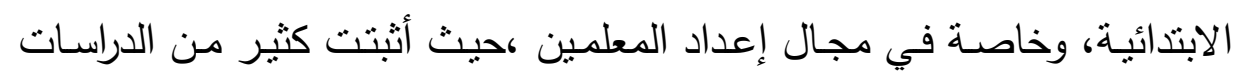

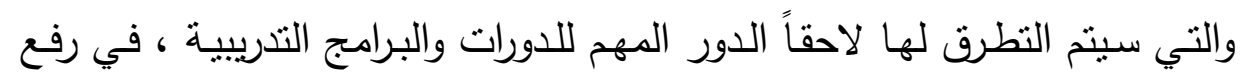

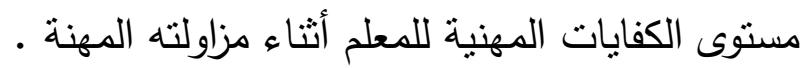

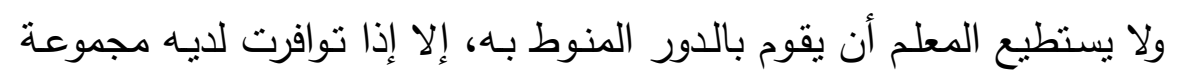

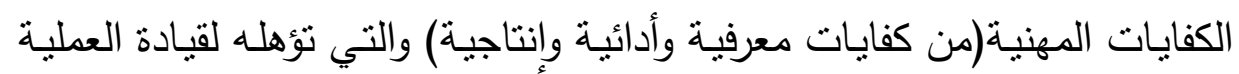

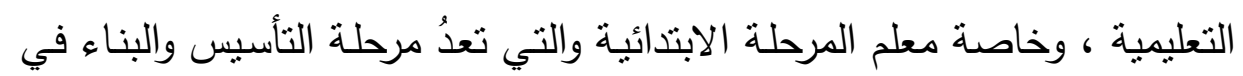

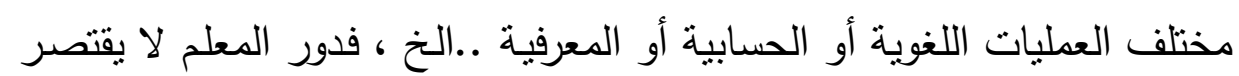

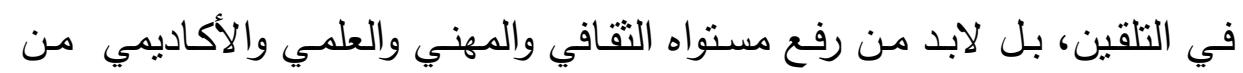

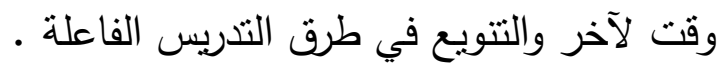

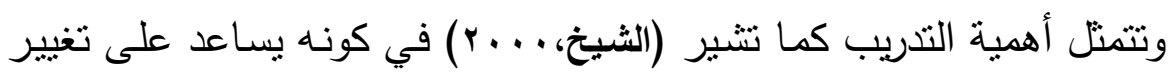

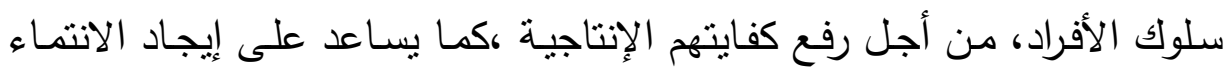

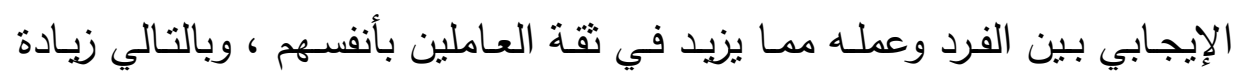

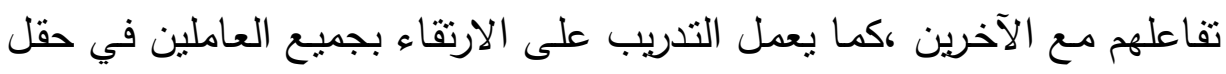

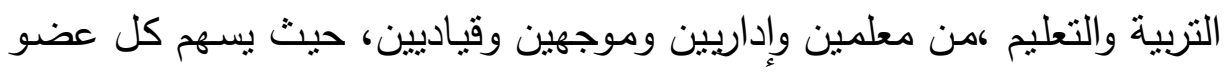
في التدريب بما يتلاءم مع مهنته.

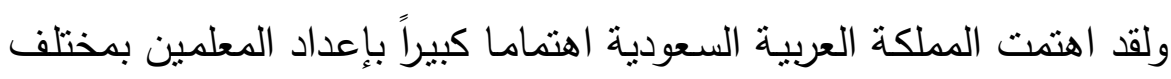
مراحل التعليم الابتدائي والمتوسط والثنانوي ، فهناك برامج تدربيية تقام في مراكز

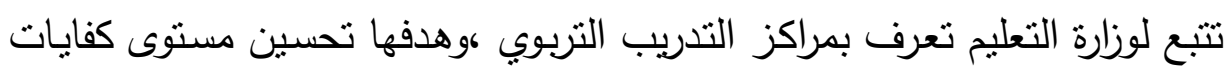
المعلم في جميع المراحل حتى ينعكس أثر ذلك على المتعلمين ،ومسايرة التقدم

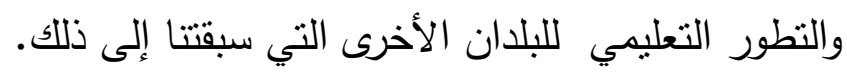

إن البرامج التدريبية ينبغي أن تكون قادرة على رفع معنويات الموظفين ،وزيادة النيان

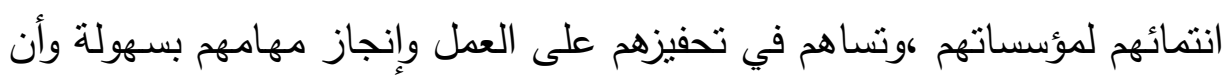


تكون قادرة أيضاً على صقل مهاراتهم ،ورفع كفاءتهم ،ومواكبتهم بكل ما هو جديد

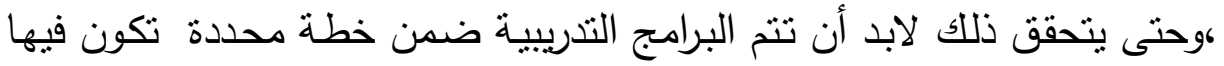
الأهداف واضحة وواقعية ،ومتماثية مع الاحتياجات الفعلية للمتدربين

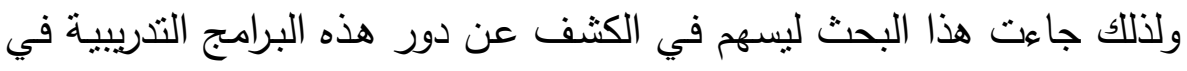

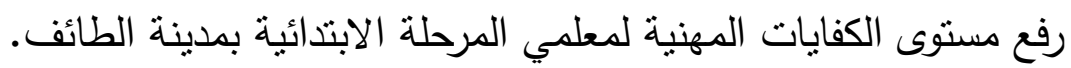
مشكلة الدراسة : مينائ يُعد المعلم من العناصر الفاعلة في العملية التعليمية؛ حيث لا يقتصر دوره

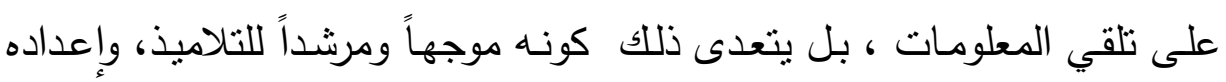

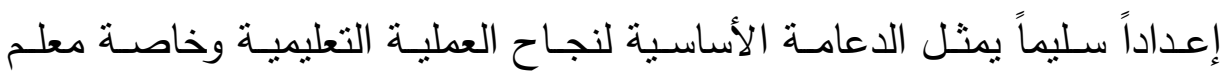
المرحلة الابتدائية .

" فمحتوى البرامج القديمـة في التعليم العـام قليل الارتبـاط عـادة للاحتياجـات

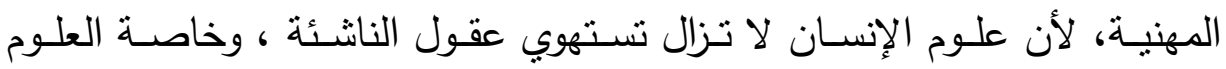

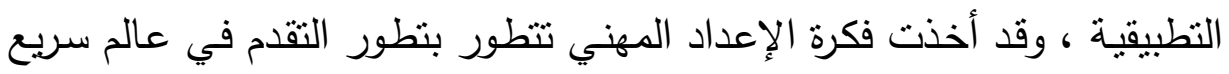

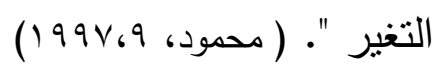

ومن منطلق أهمية البرامج التدريبية لمعلمي المرحلة الابتدائية والتي تعد مرحلة

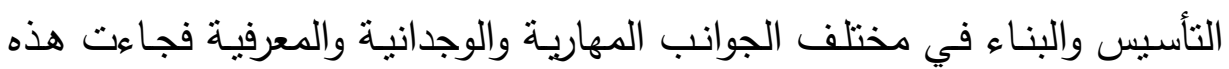

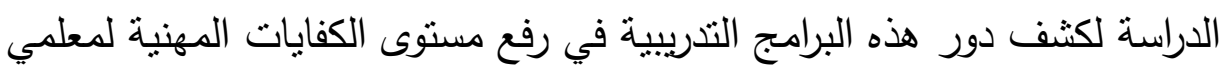
المرحلة الابتدائية من وجهة نظر المعلمين أنفسهم في هذه المرحلة. أسئلة الاراسية: الاستة

السـؤال الـرئيس : مـا دور البـرامج التـريبيـة في رفـع مسـتوى الكفايـات المهنية لمعلمي المرحلة الابتائية، من وجهة نظر المعلمين في مدينة الطائف الئف ؟ ويتفرع من هذا السؤال الرئيس ، الأسئلة الفرعية لتالية:

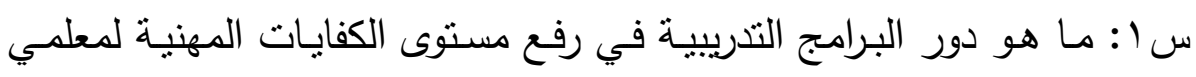
المرحلة الابتدائية، من وجهة نظر المعلمين في مدينة الطائف؟ 
س ب: ما الفروق ذات الدلالة الإحصائية عند مستوى الدلالة (a=0.05 ) بين وجهات نظر المعلمين تجاه دور البرامج التدريبية المقدمـة من وزارة التعليم في رفع مستوى الكفايات المهنية للمعلمين أثتاء الخدمة تعزى إلى، المؤهل العلمي، والخبرة في التعليم، والتخصص؟

\section{أهداف الدراسة :}

() إيضاح فلسفة البرامج التدربيية في الأدبيات التربوبة المعاصرة.

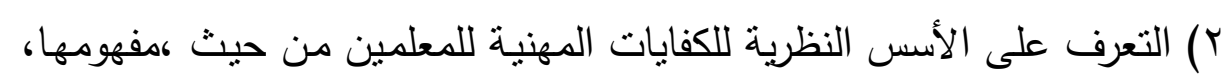
أنواعها ،خصائصها ،مبادئها الأساسية.

r) الكثف عن واقع البرامج التذريبية المقدمة للمعلم من قبل وزارة التعليم ودورها في رفع مستوى الكفايات المهنية لمعلمي المرحلة الابتدائية . ع) إيضـاح الفـروق ذات الدلالــة الإحصـائية التي تعـزى إلـى متغيـرات المؤهـل العلمي، والخبرة في التعليم والتخصص •

\section{أهمية الدراسةة}

()ثفيد المخططين والقائمين على إعداد البرامج التدريبية في وزارة التعليم إلى تلافي نقاط الضعف التي تكون في البرامج التدريبة التي سبق تقديمها ـ r)ثقديم مقترحات لصانعي القرارات التعليمية بمكن أن تحسن من جودة البرامج التدريبية في رفع مستوى النمو المهني للمعلمين ليصبحوا أكثر فاعليـة من وجهة نظر معلمي المرحلة الابتدائية بمدينة الطائف .

ب)تساهم في الكثف عن دور البرامج التدريبية في رفع مستوى الكفايات المهنية

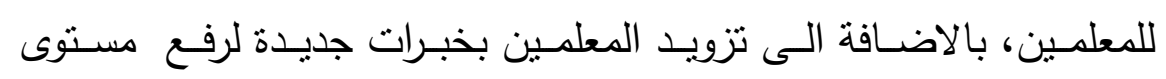
الكفايات المهنية. منهج الدراسة: تتبع الدراسة المنهج الوصفي وبعد من أنسب المنـاهج للدراسـة الحالية ،حيث يقوم الباحث بجمع المعلومات وتبوبيها وتحليلها وتفسيرها. مصطلحاث الدراسة: 


\section{التعريف لكلمة دور:}

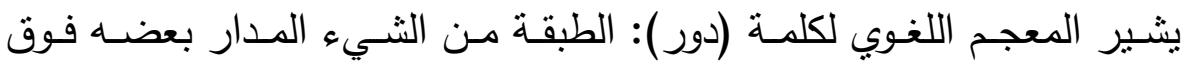
بعضه، يقال : انفسخ دور عمامته. والدور (عند المناطقة): نوقف كل من الثنه الثيأينين

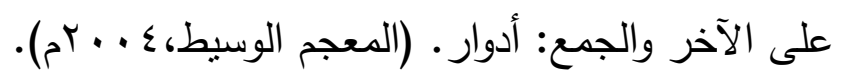

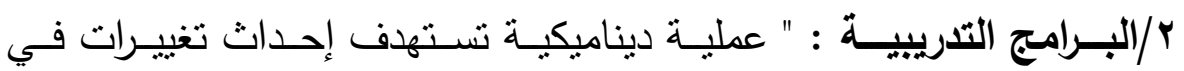

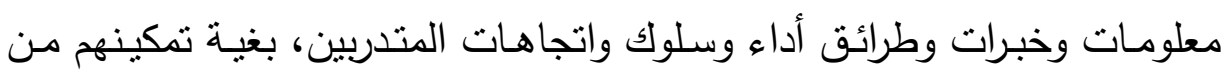

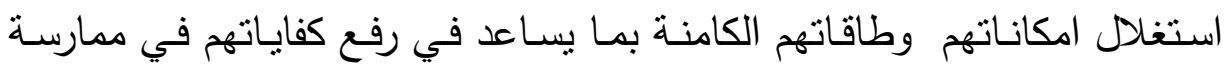

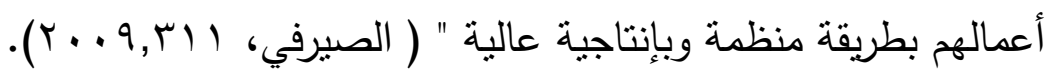

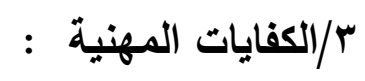

" مجموعة من القدرات و ما يرتبط بها من مهارات يفترض أن المعلم يمتلكها

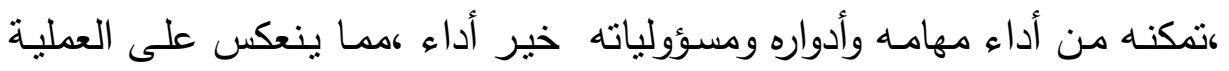

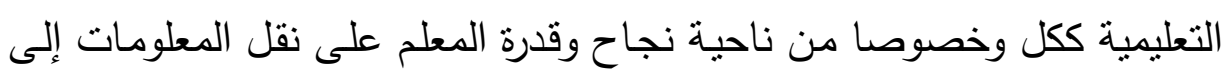
طلبته ،وقد يقوم المعلم بذللك عن طريق التخطيط والإعداد للدرس، وغيرها من

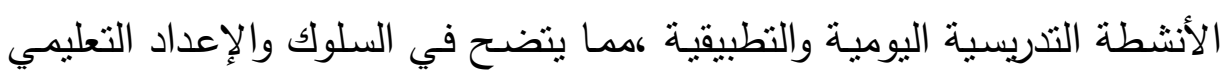

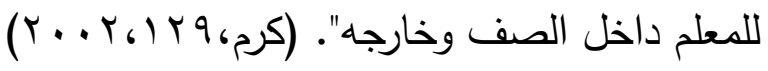

$$
\begin{aligned}
& \text { حدود الدراسة : }
\end{aligned}
$$

الحدود الموضوعية : دور البرامج التدربيية في رفع مستوى الكفايات المهنية

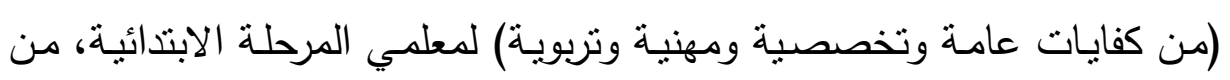
وجهة نظر المعلمين بمدينة الطائف .

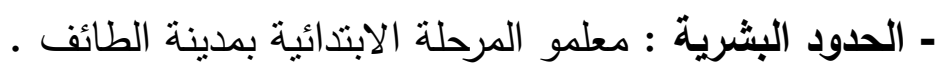

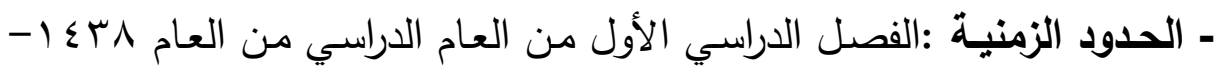
ه) $\leqslant$ १

- الحـدود الجغرافيـة المكانيـة : يتم التطبيق على مدينـة الطـائف بمواقـع إدارة التعليم ( شرق - غرب . جنوب - شمال)دون المحافظات التابعة لها. 


\section{الاراسات السابقة}

\section{• الاراسات العربية للمحور الأول: البرامج التدريبية}

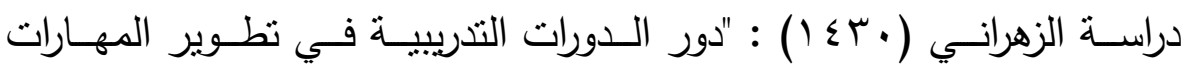

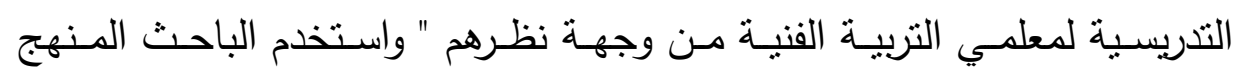

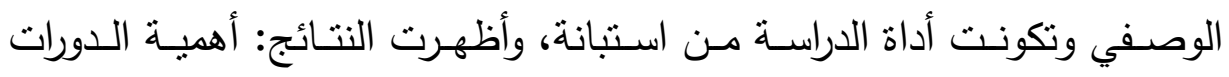
التدريبية لمعلمي التربية الفنية ، استفادة معلمي التربية الفنية من الدورات التدريبية

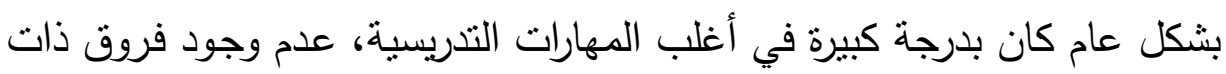

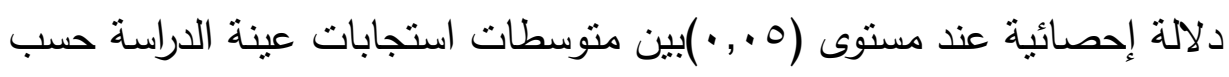
الدورات التدربيية.

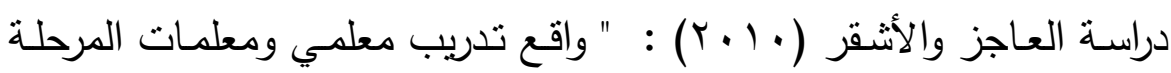

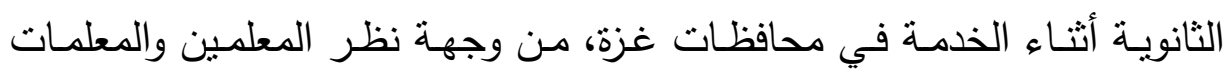

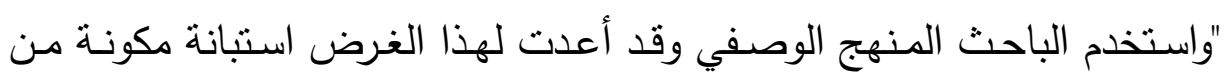

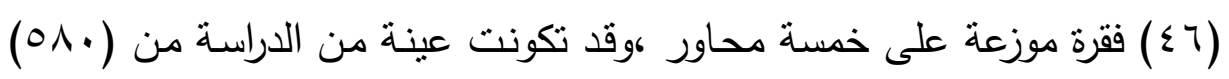

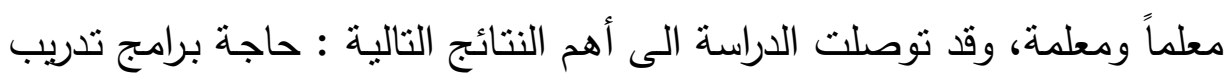
المعلمين والمعلمات إلى وجود أهداف محددة سلفاً، حاجة تدريب برامج المعلمين

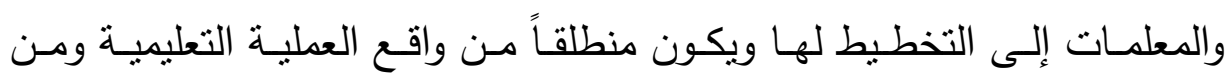
احتياجات المتدربين المختلفة ،وأهمية مشاركة المعلمين في كافة عمليات البرامج

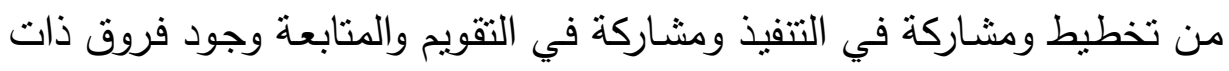
دلالة إحصائية في تدريب المعلم أثناء الخدمة في المدارس الثانوية في محافظات

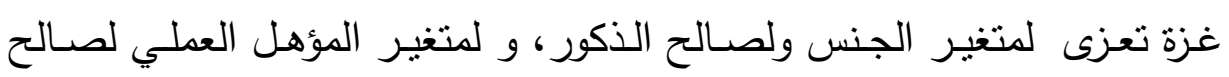

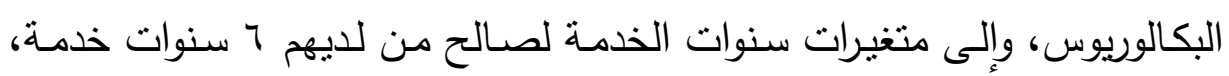
وإلى متغير عدد الدورات لصالح من لديه دورتان فأكثر .

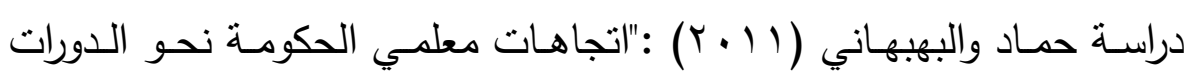

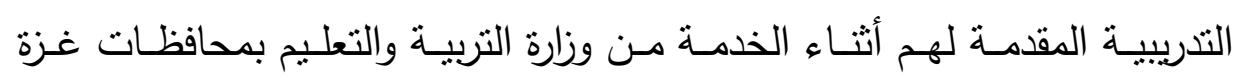


"واستخدم الباحثان المنهج الوصفي وتكونت أداة الدراسـة مـن استبانة وأظهرت

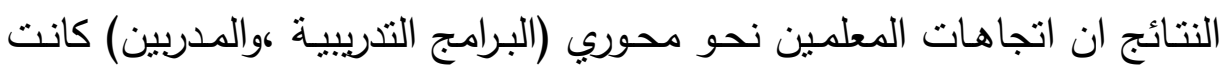
إيجابية ونحو ( البيئة التدرييية، والوقت) كانت محايده والمجموع الكلي إيجابي،

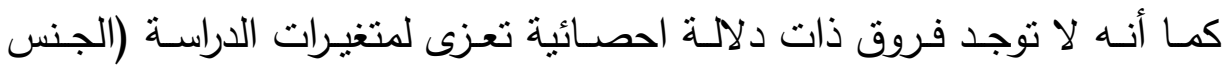
والمؤهل العلمي وسنوات الخدمة ) كما أنشارت النتائج إلى وجود فروق ذات دلهات دلالة إحصائية نحو البيئة التدريبية.

\section{ب/ الدراسات الاجنبية للمحور الأول/البرامج التدريبية}

دراسـة (Haslinda,2009) :" فعاليـة التدريب والتطوير في مختلف الوزارات والأقسام التابعة للقطاع العام في ماليزيا لإقليمي كوالالمبور ، وبتراقاي " منهج

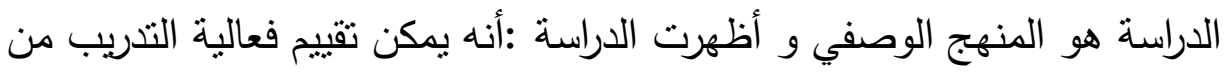
خلال خمس مستويات ،وهي رد الفعل ،والتعلم ،وتغير السلوك والنتائج ،والعائد من الاستتمار ، فقي مستوى رد الفعل أظهر المشاركين تقديرهم لعملية التدريب وبالتالي قدرتهم على إحراز مستوى عالي من التعلم ،وفي مستوى تغير السلوك تم تقييم المبحوثين من خلال تقدمهم وتغيراتهم السلوكية من خـال إختبار مهاراتهم ومعارفهم ومواقفهم المكتسبة ،وفيما يتعلق بمستوى النتائج :فقد تبين أن البرامج

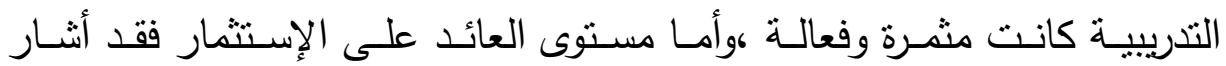
المبحوثين في الدراسة بأن البرامج التدريبية سوف تشاعدهم بتقديم مساهمات كبيرة

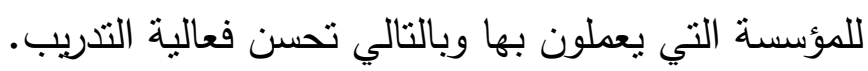
دراسـة كابوسوزغلو وبالابـان (Kapusuzoglu \& Balaban ) : " أدوار مشرفي المرحلة الأساسية في تدريب المعلمين على وظائفهم " مستخدمين في ذلك لكان

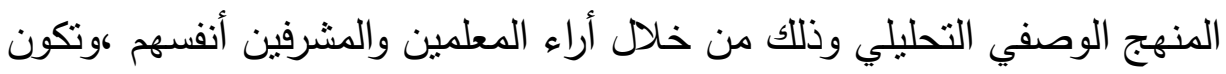

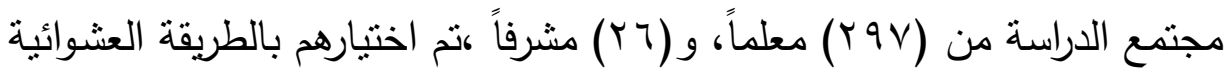

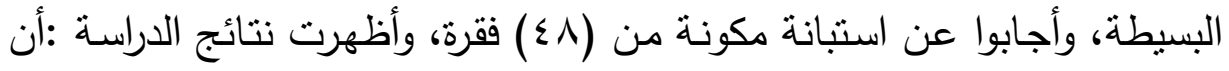
المعلمين لم يتلقوا دعماً كافياً من المشرفين ،بينما رأى المشرفين أنهم أدوا أدوارهم بشكل كبير وكبير جداً. 
Suleman, Aslam, ) دراسـة سليمان، وإسـلام، وحبيب، وجاويد، وامبرين (Habib, Javed,\& Umbrin, 2011

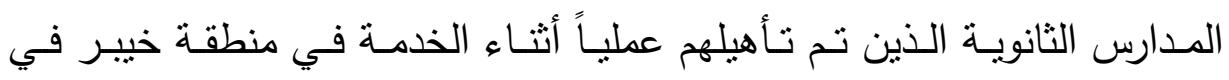

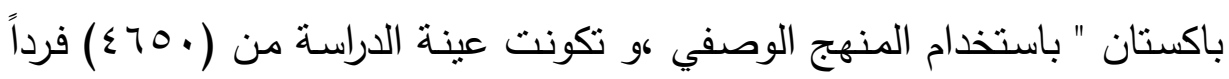

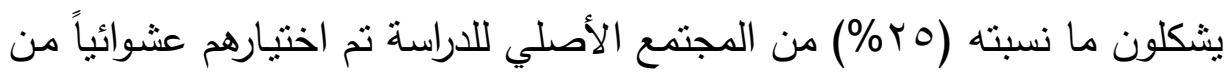

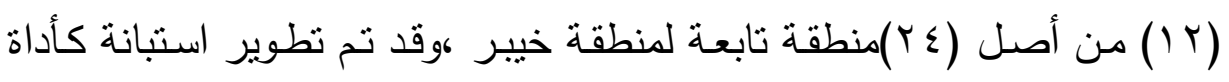

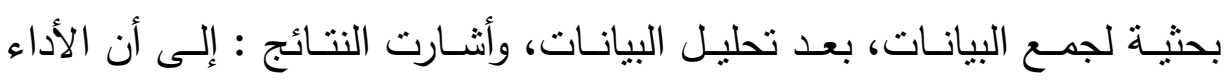

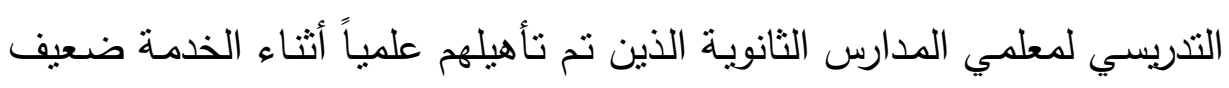

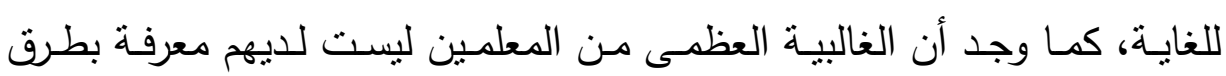
التدريس ،وغالبية الطلبة كانوا غير راضين عن طرق التدريس الخاصة بهر. الدراسات العربية للمحور الثاني/الكفايات المهنية

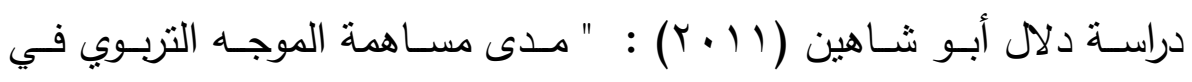
مساعدة معلمي الحلقة الأولى من مرحلة التعليم الأساسي على الكتين لــاب مهارات

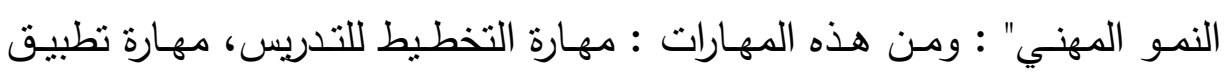

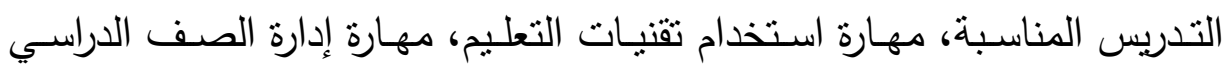

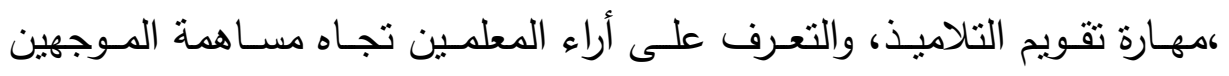

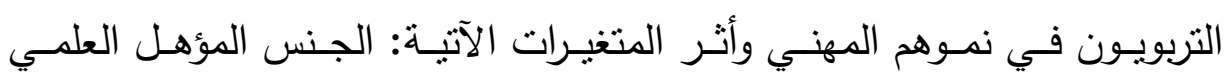
والتربوي ،الخبرة في التعليم. واستخدمت الباحثة المنهج الوصفي و تكونت عينة

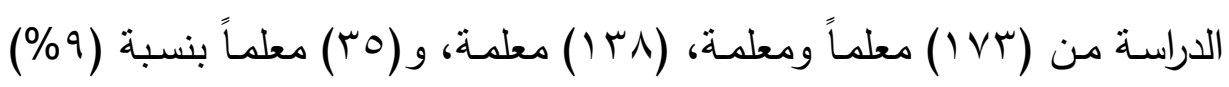

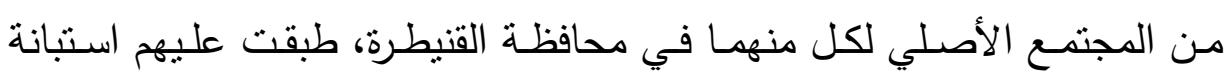

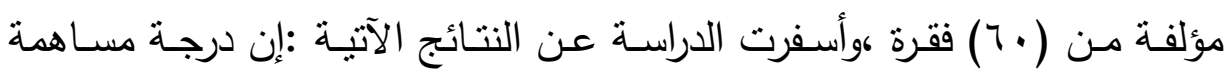

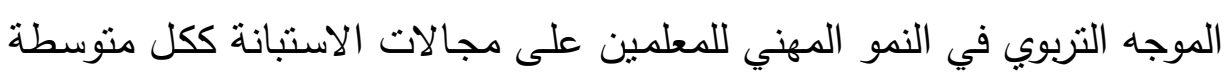

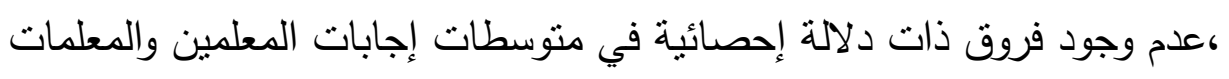

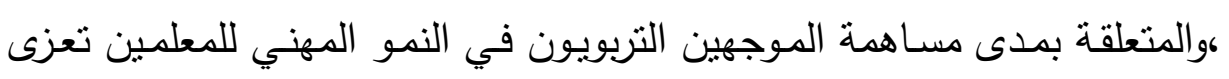

\section{Doi: $10.12816 / 0052740$}


إلـى :متغيـر الجنس بالنسـبة لكـل مجـال مـن المجـالات أو بالنسـبة لمجمـوع المجالات، وجود فروق ذات دلالة إحصـائية لإجابـات المعلمين الذين يحملون

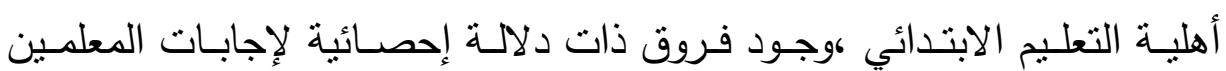

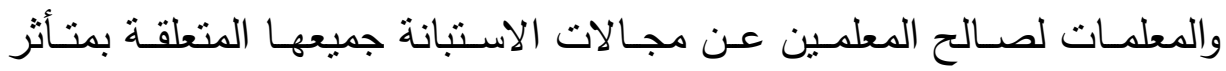
الموجهين التربويين في النمو المهني للمعلمين تعزى إلى متغير الخبرة لصالح المعلمين والمعلمات الذين لايهم خبرة عشر سنوات فأكثر . ب/ الدراسات الأجنبية للمحور الثاني/الكفايات المهنية دراسـة الك كوز ( Ac.Kgoz, 2005 ) " الكفايـات المهنيـة والثخصية

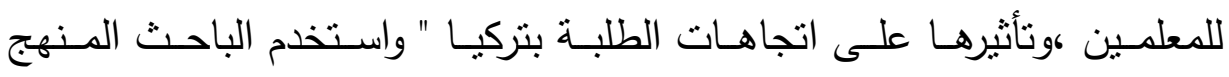
الوصفي واختيرت عينة البحث من أربع مدارس مختلفة في محافظتين في تركيا

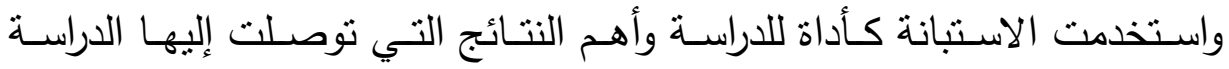
:الطالبات أكثر تأثراً بالكفايات الثخصية للمعلمين من الطلاب، والطلاب أكثر

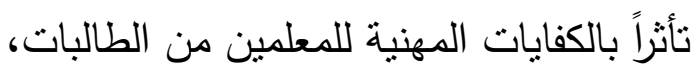

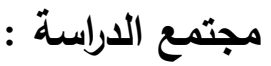

تكـون مجتمـع الدراسـة مـن جميع المعلمين في المـدراس الابتدائيـة الحكوميـة

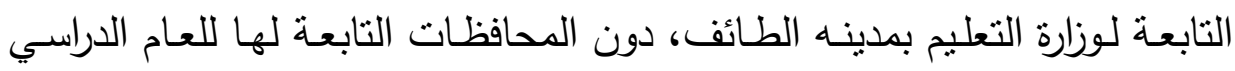

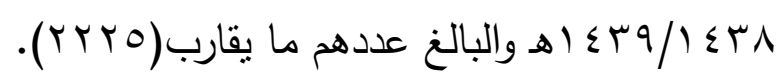
عينة الاراسة :

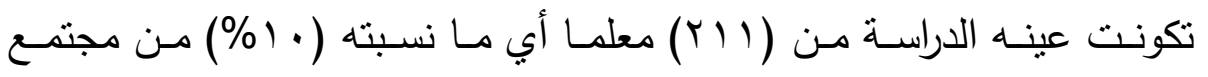

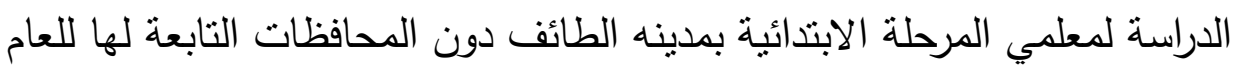

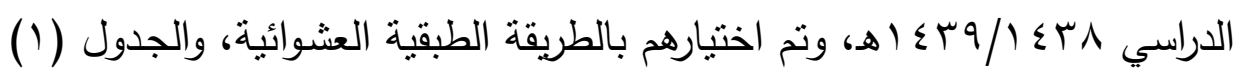
يبين توزيع أفراد عينه الدراسة. 
دور البرامج التدريبية في رفع مستوى الكفايات المهنية أ. مطلق بن سعد أحمد البرلق .

الجدول (1): توزيع عينه الاراسة حسب متغيرات التخصص ،والمؤهل

العلمي، والخبرة في التعليم للمعلمين.

\begin{tabular}{|c|c|c|}
\hline العدد العد & المستوى & المتغير \\
\hline VY & عربي & \multirow{4}{*}{ التخصص } \\
\hline ov & دين & \\
\hline Ar & تخصصات أخرى & \\
\hline YII & المجموع & \\
\hline $1 \leq 9$ & بكالوريوس & \multirow{4}{*}{ المؤهل العلمي } \\
\hline$r$ & دبلوم عالي & \\
\hline צ & دراسات عليا & \\
\hline YII & المجموع & \\
\hline rq & أقل من (0) سنوات & \multirow{4}{*}{ سنوات الخبرة في التعليم } \\
\hline r & 0 - أقل من • 1 سنوات & \\
\hline 149 & أسنوات فأكثر & \\
\hline YII & 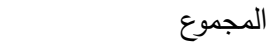 & \\
\hline
\end{tabular}

أداة الدراسة :

قام الباحث بتطوير أداة الدراسة (الاستبانة) بعد الاطلاع على الأدب التربوي

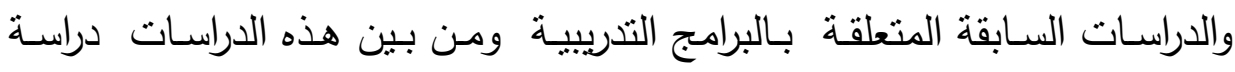

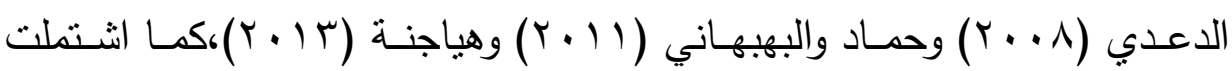
الأداة على ثلاث متغيرات مسنقلة هي التخصص ،والمؤهل العلمي ،والخبرة في وهي التعليم.

\section{صدق أداة الدراسة : صام:}

قام الباحث بعرض الاستبانة في صورتها الأولية على مجموعة من المحكمين

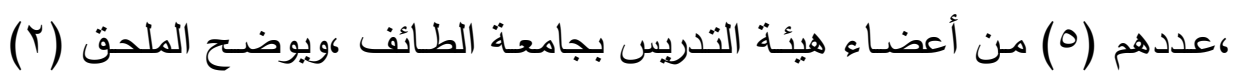

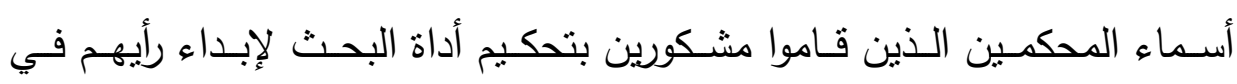

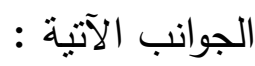


1- إنوج الاستبانة ومدى ملاعمتها للدراسة الحالية. r- معرفة مدى القرب والبعد لكل فقرة ومجالها الذي وضعت في سياقه. r- ب- بياغة العبارات لغوياً ونحوياً. ع - تغيير أو تعديل أي فقرة في الأداة تمهيدا لاعتمادها. وفي ضوء ملاحظات المحكمين قام الباحث بإجراء التعديلات اللازمة لكل فقرة

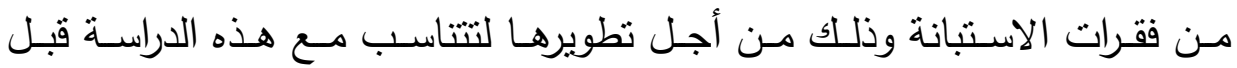
إخراجها، وبذلك أصبحت الأداة في صورتها النهائية مكونه من (rب)فقرة.

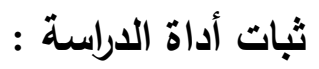
للتأكد من ثبات أداة الدراسة، استخدم الباحث طريقة الاختبار وإعادة الاختبار إذ قام الباحث بتطبيق الأداة على عينه استطلاعية مكونه من (retest -test)

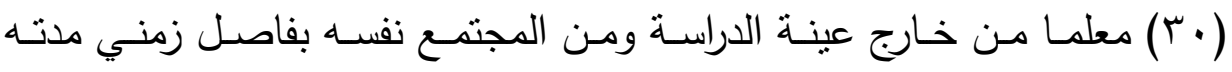
أسبوعان بين مرتي التطبيق، وتم حساب معامل الثبات باستخدام معامل ارتباط

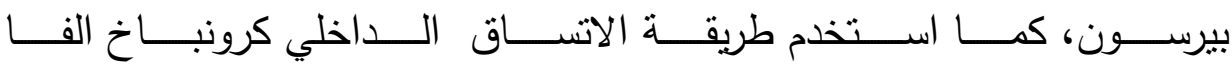
(Cronbachalpha)

الجدول (ץ) : معاملات ثبات اداة الدراسة باستخدام معامل ارتباط بيرسون

\section{وكرونباخ الفا}

\begin{tabular}{|c|c|c|c|}
\hline كرونباخ الفا & معامل ارتباط بيرسون & 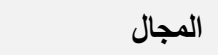 & رقم المجال \\
\hline 0.88 & 0.85 & التخطيط للاروس. & 1 \\
\hline 0.90 & 0.82 & الوسائل والأساليب & r \\
\hline 0.85 & 0.90 & الإدارة الصفية & r \\
\hline 0.79 & 0.87 & استخدام الحاسوب & $\varepsilon$ \\
\hline \multirow[t]{2}{*}{0.86} & 0.88 & التقويم & 。 \\
\hline & 0.90 & الدرجة الكلية & \\
\hline
\end{tabular}

من الجدول السـابق يتبين أن معاملات الثبات لأبعاد الاستبانة تراوحت بين

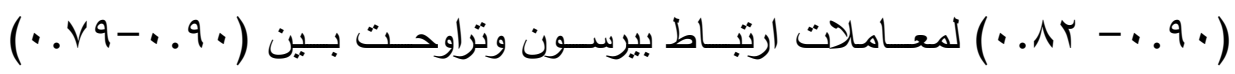


لمعاملات كرونباخ الفا وهذا يعني ان الإستبانة تتمتع بمعامل ثبات (استقرار ) مقبول لأغراض الدراسة الحالية.

\section{•المعالجة الإحصائية :}

تم استخدام المعالجات الإحصائية لأسئلة الدراسة على النحو التالي : -استخدام المتوسطات الحسابية والانحرافات المعيارية للإجابة عن السؤال الثالث؟ - استخدام قيمة (ف) وتحليل التباين الأحادي (one way anova) للإجابة

$$
\text { عن السؤال الرابع }
$$

- معامل ارتباط بيرسون ومعادلة كرونباخ الفا للتحقق من ثبات الدراسة .

$$
\text { إجراءات تطبيق أداة الدراسة: }
$$

بعد التأكد من صدق أداة الدراسة وثباتها وتحديد العينة المراد تطبيق الاستبانة

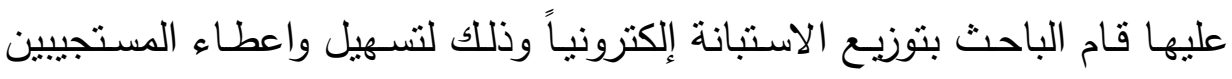

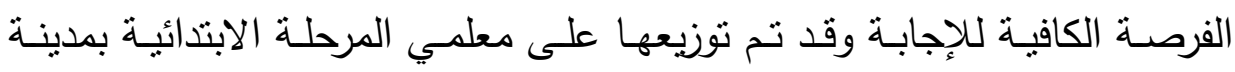

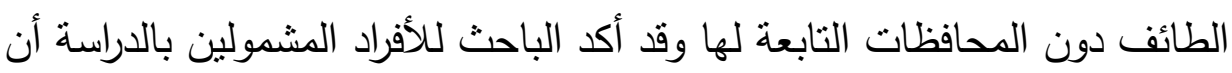

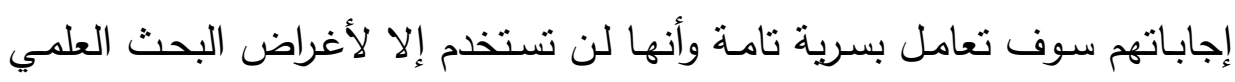

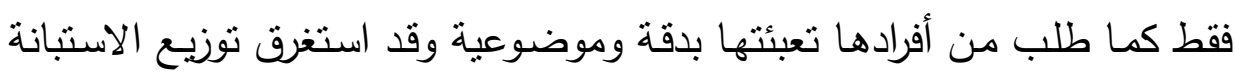

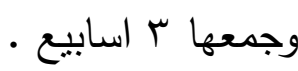
ففـي الأسـبوع الأول قـام الباحـث بالزيـارات الثخصـية والتواصـل مـع مـدراء المدارس الابتدائية بمدينة الطائف وإرسال رابط الاستبانة الإلكتروني لهم ليقوم كل

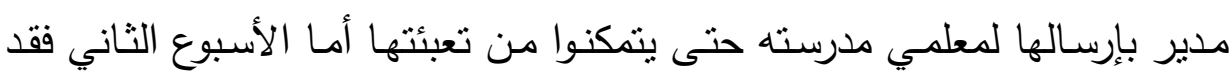

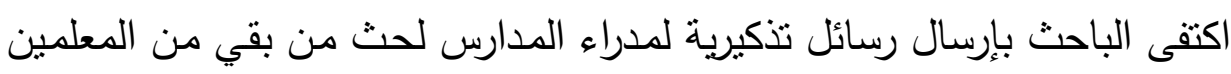

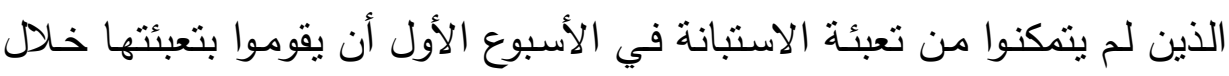

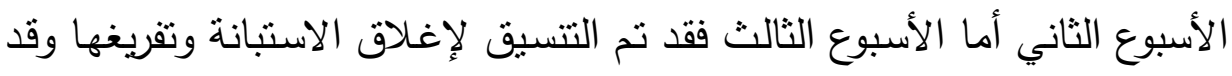

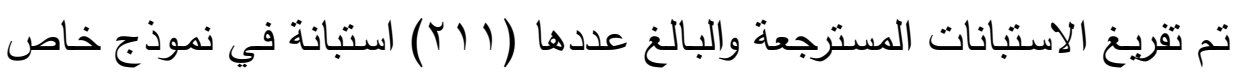
بالحاسب الآلي تمهيدا للقيام بالمعالجة الإحصائية عن طريق برنامج(spss).

\section{Doi: 10.12816/0052740}


وقد تم تدريج مستوى الإجابة عن كل فقرات الاستبانة في أربعة درجات على

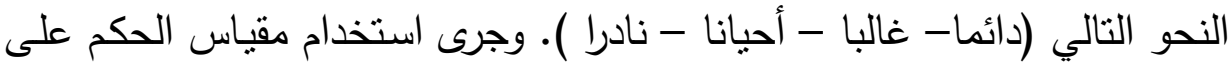
النتائج الذي تم تقسيمه إلى (منخفضة، متوسطة، كبيرة)، وفق المعادلة الاتية:

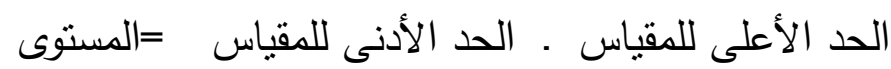

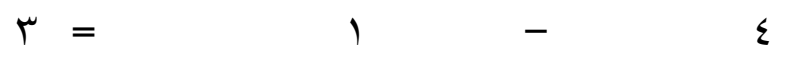

وبذللك تصبح الفئات على النحو الآتي:

\begin{tabular}{|c|c|}
\hline درجة منخفضة & من I إلى أقل من r \\
\hline درجة متوسطة & من r إلى أقل من r \\
\hline درجة كبيرة & من ؟ إلى ع \\
\hline
\end{tabular}

نتائج الاراسة :

نستعرض لأهم النتائج على النحو التالي : أولاً : النتائج المتعلّة بالإجابة على لـى السؤال الأول الذي نصّه "ما هو دور البرامج التدريبّية في رفع مستوى الكفايات

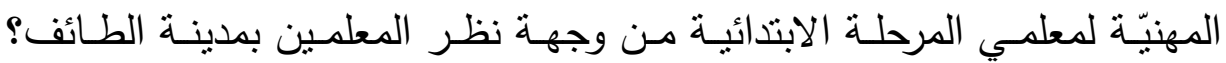

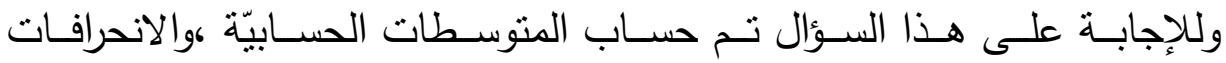
المعيارية، وتم تحديد الرتبة ودرجة دور البرامج التدريبيّة في رفع مستوى الكفايات

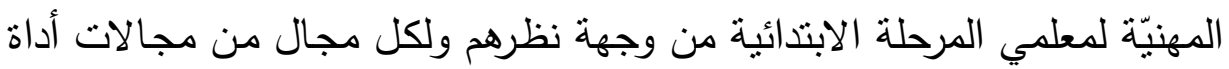

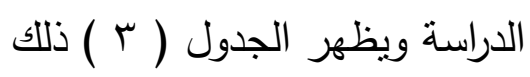

الجدول (r) : دور البرامج التدريبيّة في رفع مستوى الكفايات المهنيّة

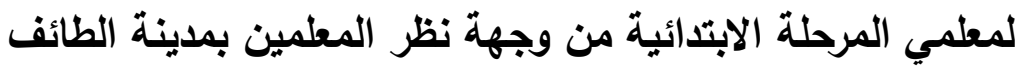

\begin{tabular}{|c|c|c|c|c|c|}
\hline الارجة & الرتبة & المعياري & المتوسط الحسابي & المجال & رقم المجال \\
\hline منوسطة & 1 & 0.62 & 2.77 & الوسائل والأساليب والأنشطة. & 2 \\
\hline منوسطة & 2 & 0.63 & 76.2 & التخطيط للاروس. & 1 \\
\hline منوسطة & 3 & 0.69 & 2.74 & التقويم & 5 \\
\hline متوسطة & 4 & 0.66 & 2.73 & الإدارة الصفيّة & 3 \\
\hline
\end{tabular}


دور البرامج التدريبية في رفع مستوى الكفايات المهنية أ. مطلق بن سعد أحمد البرلق .

\begin{tabular}{|c|c|c|c|c|c|}
\hline متوسطة & 5 & 0.75 & 2.55 & استخدام الحاسوب & 4 \\
\hline متوسطة & & 0.67 & 2.71 & & \\
\hline
\end{tabular}

يلاحظ مـن الجدول (ب) أنّ دور البـرامج التدريبيـة في رفع مسـتوى الكفايـات المهنيّة لمعلمي المرحلة الابتذائية بمدينة الطائف من وجهة نظرهم بشكل عام

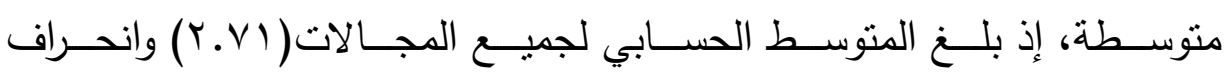

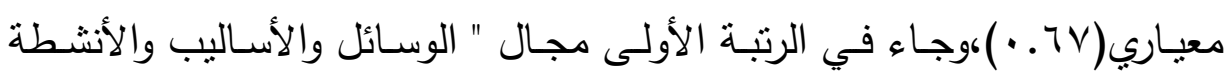
وبيئة التعلم " بمنتوسط حسابي، (Y.VV) و . وانحراف معيا(Y. . . ) وجاء في الرتبة

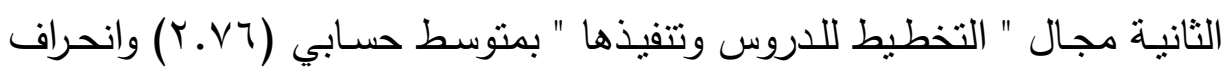

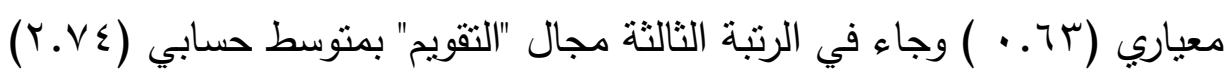
وانحراف معياري (99. . ) وجاء في الرتبـة قبل الأخيرة مجال " الإدارة الصفيّة "

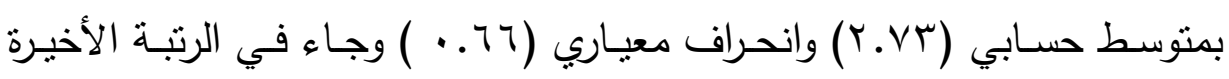

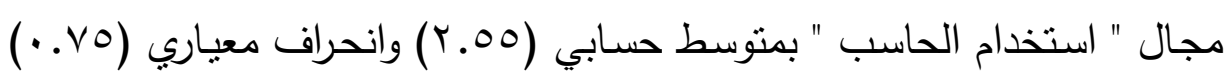
كوتعزى هذه النتيجة إلى عدة عوامل منها : اـ قلـة استيعاب هذه البرامج التدربيـة لجميع معلمي المرحلـة الابتدائية بمدينة الطائف.

r. الاهتمام بمجال الوسـائل والأسـاليب والأنشطة من قبل واضعي هذه الأنشطة قد يكون مبرراً ،لأن تقريب المعلومات لتلاميذ هذه المرحلة من قبل المعلمين يكون عن طريق استخدام مثل هذه الوسائل والأنشطة ،لذا جاء هذا المجال

$$
\text { في الرتبة الأولى. }
$$

ب. التدرج في التخطيط للاروس وتتفيذها من قبل المعلمين ، ليتتاسب مع مراحل النمو لتلاميذ هذه المرحلة ،لذا جاء في الرتبة التانية. ع. تأخر رتبة مجال الإدارة الصفية لهذه البرامج التدريبية، مما ينعكس سلبا على المعلم وقدرته على مواجهة مشكلات التلامبذ أثناء سير الحصة الدراسية. 
هـ تأخر مجال استخدام الحاسوب إلى الرتبـة الأخيرة يشير إلى اهتمام واضـي هذه البرامج وتركيزهم على المعلمين أصـحاب التخصصـات العلميـة وإهمال باقي التخصصات.

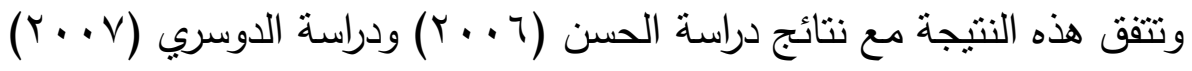

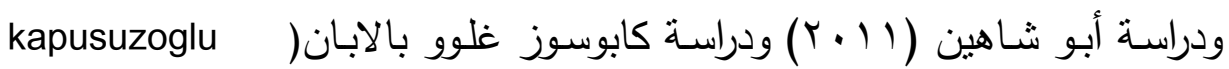
.( balaban 2010 التي اثـارت إلى وجـود مستوى متوسـط مسن دور البـرامج التدريبيـة في رفـع مستوى الكفايات المهنية للمعلمين وفي حين تختلف هذه النتيجة مع نتيجة دراسة سليمان وإسـام وحبيب وجاويد،وامبرين ) suleman, aslam, habib, javed,um 2011, ) التي أثنارت إلى أن المستوى الذي طور فيه المعلمون معارفهم ومهاراتهم في نهاية التدريب كان منخفضاً بشكل عام، وفيما بلي عرض لفقرات كل مجال

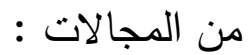

الجدول (ع) : ودرجة دور البرامج التديبية في رفع مستوى الكفايات المهنية لمعلي المرحلة الابتدائية من وجهة نظرهم فى مجال الوسائل والاسايب والأنشطة

\begin{tabular}{|c|c|c|c|c|c|}
\hline 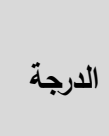 & الرتبة & المعياري الانحراف & العسابي & ساعدني البرامج التدريبي في : & رالفقرة \\
\hline متوسطة & 1 & 0.99 & 2.94 & تلتعديل أسـاليب التـدريس وفقـاً لنتـائج & 1 \\
\hline منتوسطة & 2 & 0.99 & 2.84 & التسلسل في عرض مادة التعلّم & 5 \\
\hline متوسطة & 3 & 0.96 & 2.80 & التدريس اســــام الوســـائل التعليميـــة فـــي & 2 \\
\hline منوسطة & 4 & 0.92 & 2.71 & استخدام مساحة الفصل بشكلٍ فعَال & 6 \\
\hline منتوسطة & 5 & 0.99 & 2.70 & 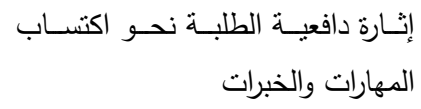 & 4 \\
\hline متوسطة & 6 & 0.93 & 2.58 & إغأغاء البيئة الصفية بالمواد المطبوعة المختلفة من عمل الطلبة & 3 \\
\hline
\end{tabular}


دور البرامج التدريبية في رفع مستوى الكفايات المهنية أ. مطلق بن سعد أحمد البرلق .

\begin{tabular}{|l|l|l|l|l|}
\hline الارجة الكلية & 0.96 & 2.76 & الاروسطة \\
\hline
\end{tabular}

يلاحظظ مـن الجدول (ع ) أن درجـة دور البـرامج التدريبيـة في رفع مسـتىى

الكفيـات المهنيـة لمعلمي المرحلـة الابتدائيـة من وجهة نظرهم لفقرات مجـال : " الوسائل والأساليب والأنشطة وبيئة التعلم " كانت متوسطة وبلغ المتوسط الحسابي

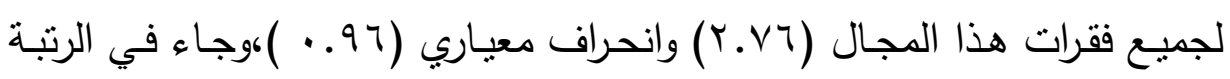
الأولى من الجدول (ع) الفقرة (1) " تعديل أساليب التدريس وفقاً لنتائج التقويم "

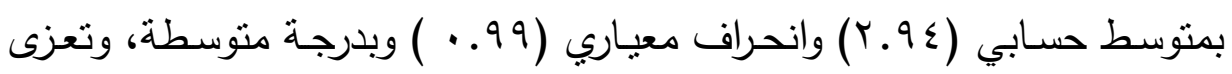
هذه النتيجة إلى أن هذه البرامج التدربيبة تراعي مـا استحدثثه الوزارة من آليات تقوبم جديدة ،لكنها في الوقت نفسه تصطدم بقلة الخبرة فيمن يقدمها للمعلمين من مشـرفين تربـوبين أو مدراء مدارس ،وجـاءت في الرتبـة الثانيـة مسن الجدول (ع)

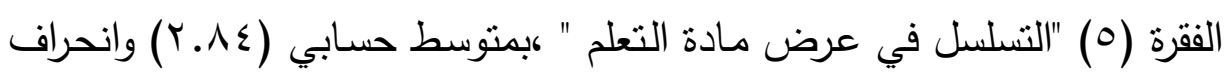
معيـاري (99 . • ) وبشكل متوسط . وتعزى هذه النتيجـة إلى ،أن هنـاك اهتمـام بشكل متوسط في تدربب المعلمين على عرض المـادة العلميسة بشكل متسلسل كلتناسب والنمو الذهني للتلاميذ. وجاء في الرتبـة قبل الأخير الفقرة (ع) " إثارة دافعيـة الطلبـة نحـو اكتسـاب المهـارات والخبـرات " بمتوسـط حسـابي ( •.V. وانحراف معياري (9 9. . ) وهذا يدل على أن هذه البرامج لديها قصور في إعداد برامج من شأنها استثمار نشاط التلاميذ وحيويتهم أثناء الحصة ودمجهم للتفاعل أثثاء الدرس ،وجـاء في الرتبـة الأخيرة الفقرة (ب) " إغناء البيئة الصفية بـالمواد المطبوعة والأدوات المختلفة ،من عمل الطلبة بمتوسط حسابي (^ه.ب) وانحراف معياري (ج9. • )وتعزى هذه النتيجة ،إلي إهمال هذه البرامج في التركيز على المحور الرئيسي من العملية التعليمية وهم التلاميذ ،وعدم الاستفادة من إبداعاتهم وثقـافتهم أثتـاء الـدرس،وتتفق هـذه النتيجـة مــع نتـائج بعـض الدراسـات السـابقة وتختلف مـع أخـرى فقد اتفقت مـع دراسـة كثـاهين (11 (Y)، ودراسـة عطـوان ( ) . . ( ) والتي أثـارت إلى معوقات في أساليب التعليم ،في حين تختلف نتائج

\section{Doi: $10.12816 / 0052740$}


الدراسة مع نتيجة دراسة (Joseph \& ping - lungm,2004) والتي أثنارت إلى أن

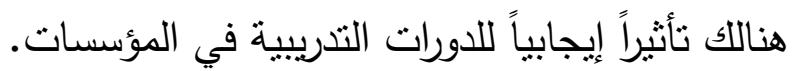
الجدول(ه) : ودرجة دور البرامج التدريبية في رفع مستوى الكفايات المهنية

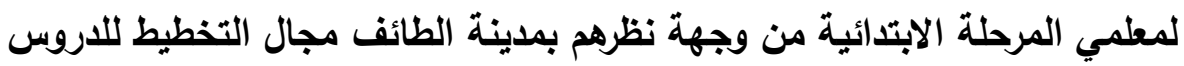
وتنفيذها

\begin{tabular}{|c|c|c|c|c|c|}
\hline الارجة & 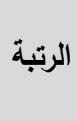 & الانحــراف & المتوســـــ & ساعدني البرامج التدريبي في : & رقة \\
\hline متوسطة & 1 & 0.99 & 2.95 & 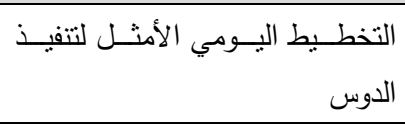 & 1 \\
\hline متوسطة & 2 & 0.98 & 2.83 & تلتمية مهارات الطلبزة على الأهداف المهاريّة في & 3 \\
\hline متوسطة & 3 & 0.94 & 2.81 & استثمار وقت الحصة بشكل فعّال & 7 \\
\hline متوسطة & 4 & 0.98 & 2.80 & 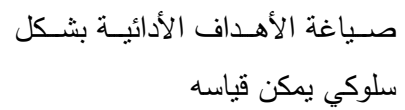 & 2 \\
\hline متوسطة & 5 & 0.99 & 2.72 & تطوبر الأدوات الفعلية التي نراعي & 6 \\
\hline متوسطة & 6 & 0.97 & 2.71 & تحليل المحتوى للمادة التعليمية & 5 \\
\hline متوسطة & 7 & 0.99 & 2.68 & التخطيط بفعالية للموقف الصفي & 8 \\
\hline متوسطة & 8 & 098 & 2.63 & تطوبر الخطط الفعليـة التي تراعي & 4 \\
\hline متوبطة & & 0.97 & 2.76 & الارجة الكلية & \\
\hline
\end{tabular}

يلاحظ مـن الجدول ( 0 ) أن درجـة دور البـرامج التذريبيّة في رفع مستنوى

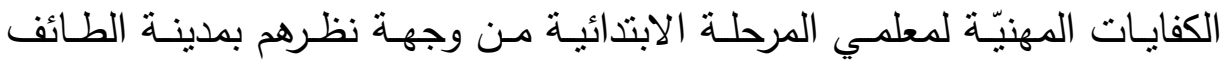

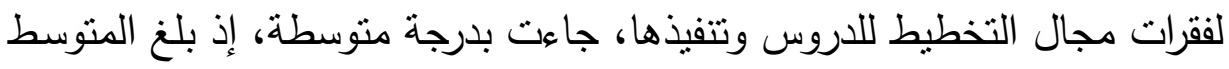

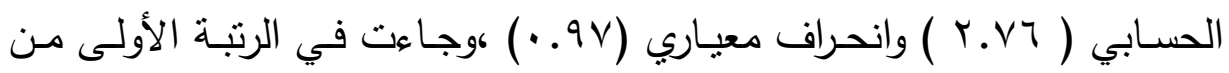

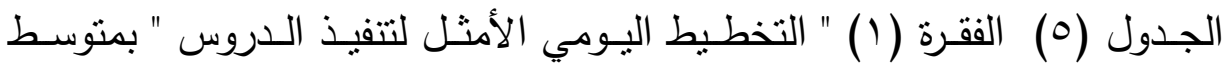


حسابي ( 90 . ) وانحراف معيـاري ( 99. . . ) وبدرجـة متوسـة وتعزى هذه

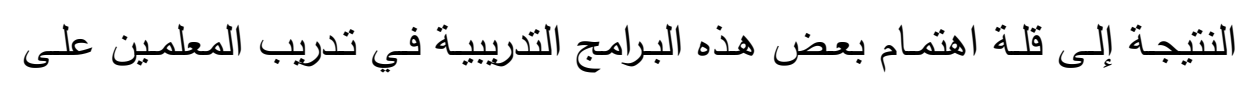
التخطيط اليومي لمسايرة المنهج ،والاكتفاء بالتخطيط التقليدي في تتفيذ الدرس، وجـاءت في الرتبـة الثانيـة مـن الجدول (0) الفقرة (ب) " التركيز على الأهداف

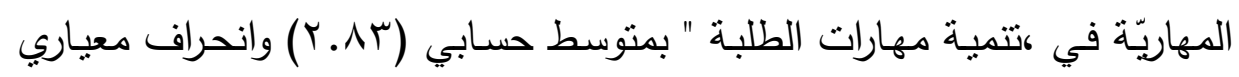
(1^ . • ) وبدرجة متوسطة، وتعزى هذه النتيجة إلى عدم المعرفة الحقيقيـة من

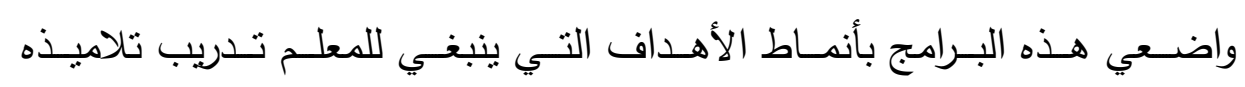
عليها،وجاءت في الرتبة قبل الأخيرة الفقرة (^) " التخطيط بفعالية للموقف الصفي

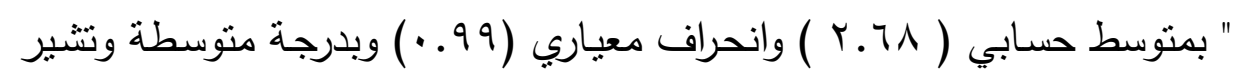

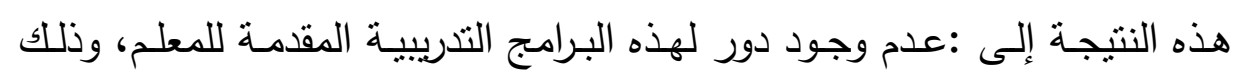
بجعله منفذ للموقف الصفي لا مخطط.،وجـاءت في الرتبـة الأخيرة الفقرة (ع) " تطوير الخطط الفعلية التي تراعي حاجات الطلبة " ،بمتوسط حسابي ( سج.r ) وانحراف معياري ( 9^. • )وبدرجة متوسطة، وتعزى هذه النتيجة، إلى قصسور البرامج التدربيية في تطوير الخطط التي تراعي حاجات الطلبة أثناء التدريس مما ينعكس سلباً على أدائهم وتمكنهم من المادة العلمية .

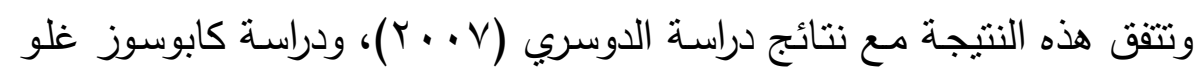
وبالابان (kapusuzoglv \& balaban 2010) التي أشارت إلى أن مستوى المعلمين في التخطيط للتدربس جاء بشكل متوسط، في حين تختلف هذه النتيجة مـع نتيجة

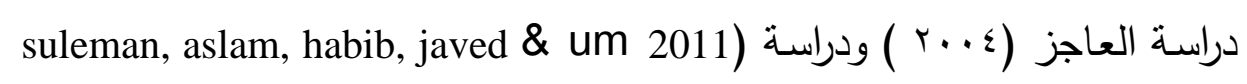
التي أثنارت إلى أن مستوى مشاركة المعلمين في التخطيط للتدربب كان منخفضاً 
الجدول (†): دور البرامج التدريبية في رفع مستوى الكفايات المهنية لمعلمي المرحلة الابتدائية بمدينة الطائف من وجهة نظر المعلمين فى مجال تقويم أداء

\begin{tabular}{|c|c|c|c|c|c|}
\hline الدرجة & الرتبة & الانحـراف & المتوســـــ الحسبي & ساعدني البرامج التدريبي في : & رقاق \\
\hline منوسطة & 1 & 0.96 & 2.84 & تعريـ طـرق التقـوبم المناسـبة في تتميـة & 1 \\
\hline متوسطة & 2 & 1.00 & 2.81 & لمراعـاة الفروق الفرديّة بين الطـلة المتدرجـة في الصــوبة & 3 \\
\hline منوسطة & 3 & 1.00 & 2.73 & معالجة نقاط الضعف عند الطلبة & 4 \\
\hline منوسطة & 4 & 1.00 & 2.72 & بناء الاختبارات وفقاً لجدول المواصفات & 6 \\
\hline منتوسطة & 5 & 1.00 & 2.70 & بناء أدوات تقويم مناسبة & 2 \\
\hline متوسطة & 6 & 1.00 & 2.62 & تطوير اختبارات تقيس تحصيل الطلبة & 5 \\
\hline منتوسطة & & 0.993 & 2.73 & الدرجة الكلية & \\
\hline
\end{tabular}

يلاحظ من الجدول (T) أن درجة دور البرامج التدريبية في رفع مستوى الكفيات المهنية لمعلمي المرحلة الابتدائية بمدينة الطائف من وجهة نظر المعلمين لفقرات

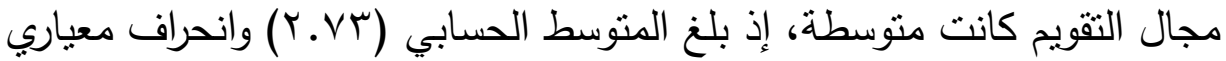

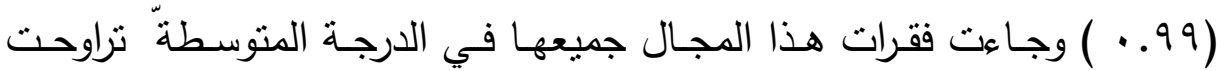

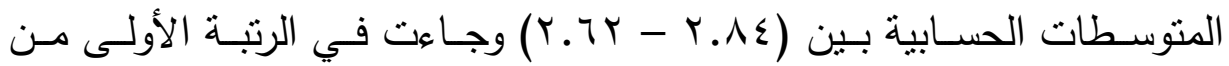
الجدول (7) الفقرة (1) والتي تنص " تعريف طرق التقويم المناسبة في تتميـة

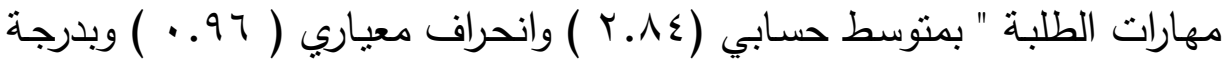
منوسطة وتعزى هذه النتيجة إلى أن تعريف طرق التقويم المناسبة لتتمية مهارات

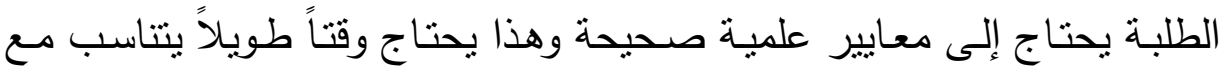
الموضوع، ومن خلال اختبارات معينة وأثخاص محددين وليس لجميع المعلمين، 
لذلك جاء دور البرامج التدريبيـة بدرجـة متوسطة.وجاءت في الرتبـة الثانيـة من

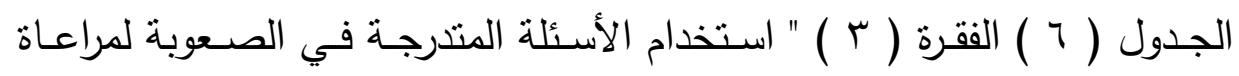

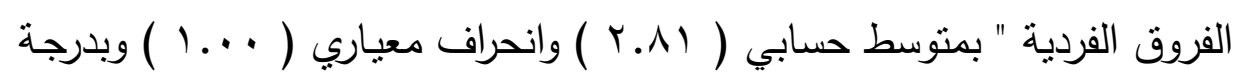

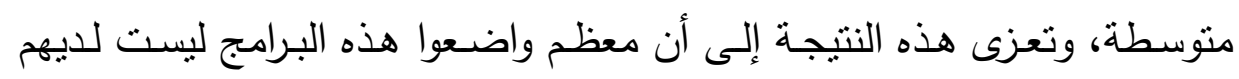
مهارات في القياس والتقويم، وتطوير المعلمين في هذا الجانب وبخاصنة المعلمين إندين

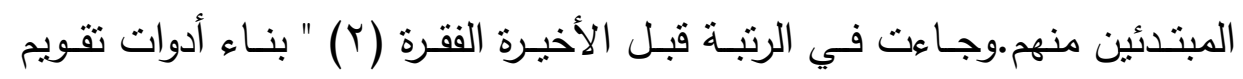

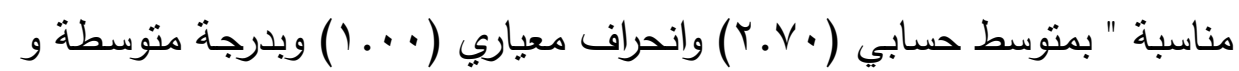
تعزى هذه النتيجة إلى عدم وجود متخصصين لبنـاء مثنل هذه الادوات لكي

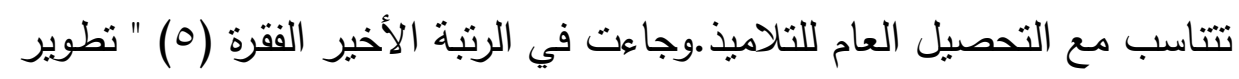

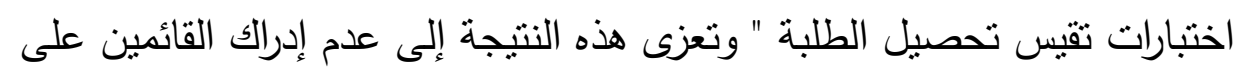

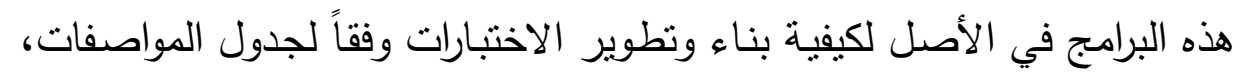

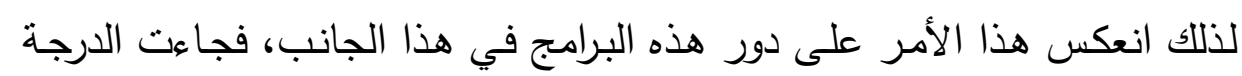

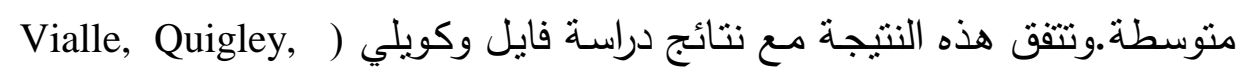

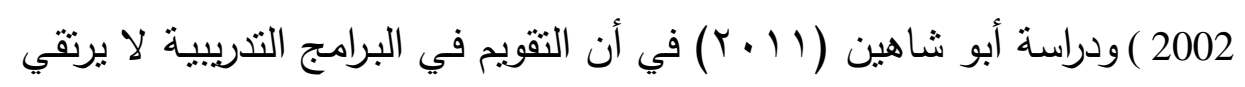

$$
\text { للمستوى المطلوب المدول }
$$

الجدول ( V ) : دور البرامج التدريبية في رفع مستوى الكفايات المهنية لمعلمي

المرحلة الابتدائية بمدينة الطائف من وجهة نظرهم فى مجال الإدارة الصفية

\begin{tabular}{|c|c|c|c|c|c|}
\hline الدرجة & الرتبة & المعباري & الحسابي & ساعنى البرامج التريبي في : & رالفقرة \\
\hline متوسطة & 1 & 0.95 & 2.93 & توزيع وقت الحصة على الفعاليات بشكل & 1 \\
\hline متوسطة & 2 & 0.99 & 2.76 & التعامل مع سلوكيات الطلّبة بشكل فعال & 2 \\
\hline متوسطة & 3 & 0.99 & 2.75 & 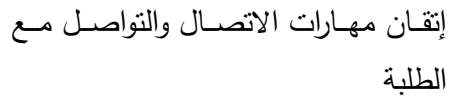 & 3 \\
\hline
\end{tabular}




\begin{tabular}{|c|c|c|c|c|c|}
\hline متوسطة & 4 & 0.98 & 2.70 & تنظيم عمل مجموعات الطلبة & 5 \\
\hline منوسطة & 5 & 0.99 & 2.69 & تشويق الطلبة لموضوع الدرس & 6 \\
\hline متوسطة & 6 & 0.99 & 2.57 & تنظيم ملفات الطلبة وأعمالهم اليدوية & 4 \\
\hline متوسطة & & 0.98 & 2.73 & \multicolumn{2}{|c|}{ الارجة الكلية } \\
\hline
\end{tabular}

يلاحظ من الجدول (V) أن درجة دور البرامج التدريبية في رفع مستوى الكفيات

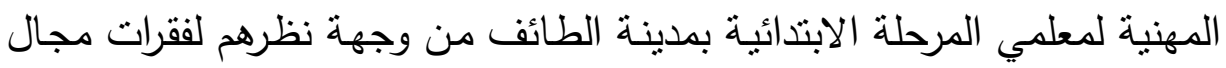

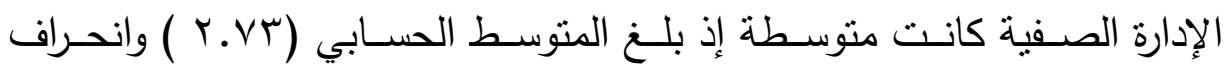

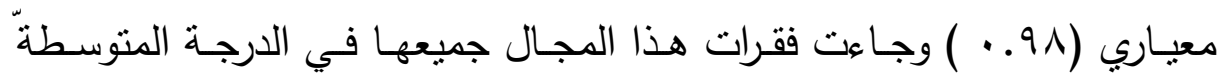

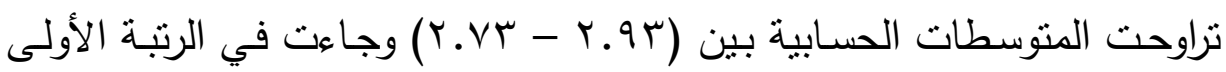

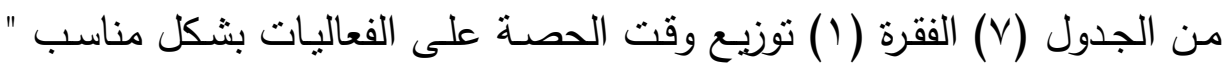
بمتوسط حسابي (ب.9.4) وانحراف معياري (90. • ) وبدرجة منوسطة وتعزى هذه

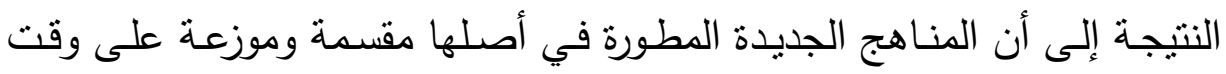

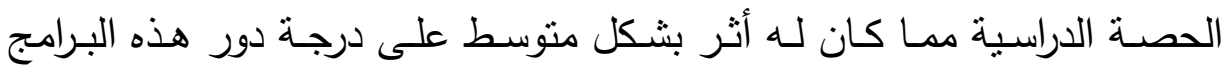

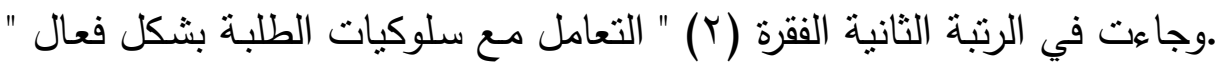

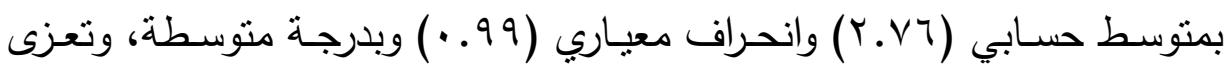

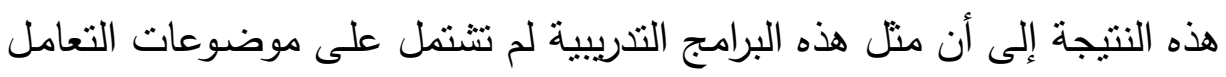

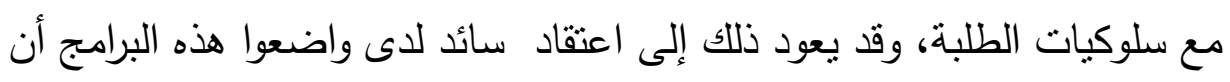

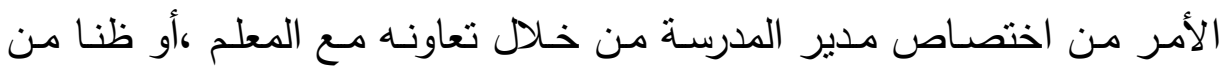

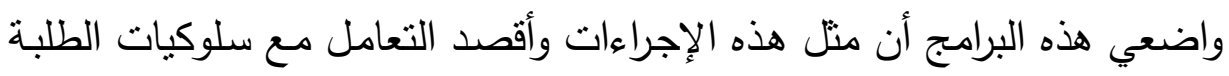
من اختصاص المرشد الطلابي فقط.وجاءت في الرتبـة قبل الأخيرة الفقرة (؟) "

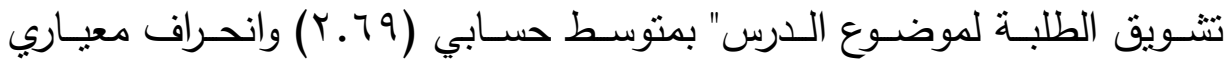
(99. • ) وبدرجة متوسطة و تعزى هذه النتيجة إلى قصور المحتوى التدريبي في

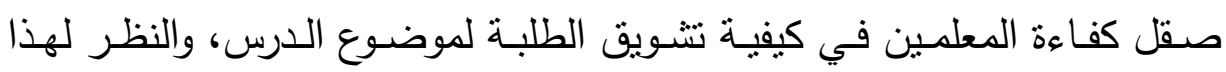

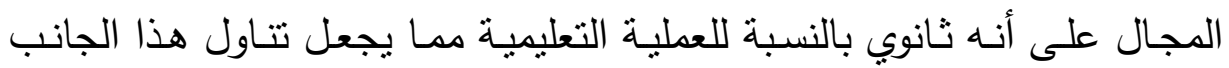
roo 
خلال البرنامج التدريبي تتاولاً غير مباشر وهذا قد انعكس على درجة دور البرامج فجاءت متوسطة.

وجاءت في الرتبة الأخيرة الفقرة (ع) " تتظيم ملفات الطلبة وأعمالهم اليدوبـة "

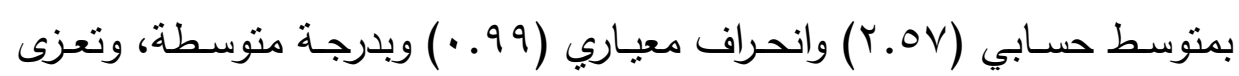
هذه النتيجة إلى عدم اهتمام البرامج التدريبية لمثل هذه الموضوعات من نرتيب وتتظيم الملفات وأعمال الطلبة ،وأن منلهذه الموضوعات يكفي فيها توجيه المعلم للتنامبذ.

وتتفق هذه النتيجة مـع نتائج دراسـة كابوسوزغلو بالابـان(2010) التي اشـارت إلى وجود مستوى متوسط لدورهذه البرامج التدريبيـة في النمو المهني،في حين تختلف هذه النتيجة مـع نتيجة سليمان وإسـلام وحبيب وجاويد وإمبرين( (1 ( ب). Vialle, التي اثـارت إلى أن المستوى كان منخفضـاً. ودراسـة فايـل وكويلي ( Quigley, 2002 يصبحوا أقدر على التعامل مع الطلبة. الجدول (^): ودرجـة دور البرامج التدريبيـة في رفع مستوى الكفايـات المهنيـة لمعلمي المرحلة الابتذائية بمدينة الطائف من وجهة نظر المعلمين لفقرات مجال

\begin{tabular}{|c|c|c|c|c|c|}
\hline الارجة & الرتبة & 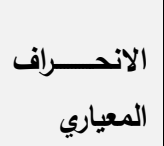 & الحستوســـــ ط المسب & ساعدني البرامج التدريبي في : & رقا لفقرة \\
\hline متوسطة & 1 & 0.98 & 2.74 & استخدام الحاسوب بفعاليّة & 1 \\
\hline متوسطة & 2 & 0.99 & 2.59 & بالتقنية الخبرات لابتكار دورس غنيـة & 5 \\
\hline متوسطة & 3 & 0.99 & 2.56 & 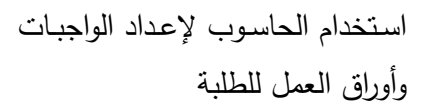 & 2 \\
\hline متوسطة & 4 & 0.99 & 2.48 & دمج التكنولوجيا في التدريس & 4 \\
\hline
\end{tabular}




\begin{tabular}{|c|c|c|c|c|c|}
\hline متوسطة & 5 & 0.99 & 2.46 & دي الأعمال اليومية مختلفة مـن البرمجيـات & 6 \\
\hline متوسطة & 6 & 0.99 & 2.45 & 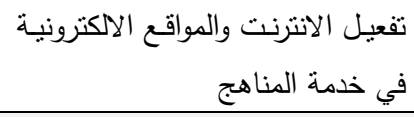 & 3 \\
\hline متوسطة & & 0.98 .83 & 2.54 & \multicolumn{2}{|c|}{ الدرجة الكلية } \\
\hline
\end{tabular}

يلاحظ من الجدول (^) أن درجة دور البرامج التدريبية في رفع مستوى الكفيات المهنيـة لمعلمي المرحلـة الابتدائيـة بمدينـة الطـائف مـن وجهـة نظـر المعلمين،

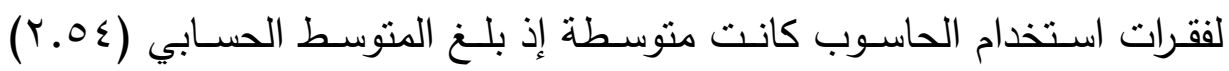
وانحـراف معيـاري (19 . • ) وجـاءت فقـرات هـذا المجـال جميعهـا في الدرجـة

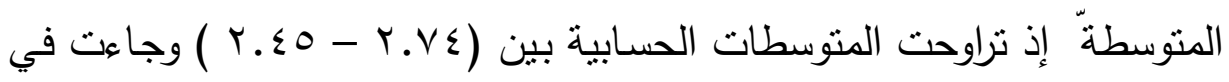
الرتبـة الأولى مـن الجـدول (^) مـن فقـرات هـذا المجـال الفقـرة ( () " اسـتخدام

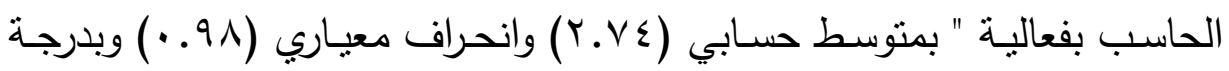
متوسـطة وتعزى هـذه النتيجـة إلى أن اسـتخدام الحاسـوب، قليـل جـدا مـن قبـل

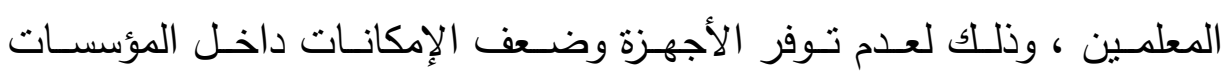
التعليميـة، والاعتمـاد على الوسـائل التقليديـة، واقتصارحضـور هذه البرامج على معلمي التخصصسات العلميـة ذات الصـلة.وجاءت في الرتبـة الثانيـة من الجدول (^) الفقرة (0) من فقرات هذا المجال وهي " تبادل الخبرات لابتكار دروس غنية

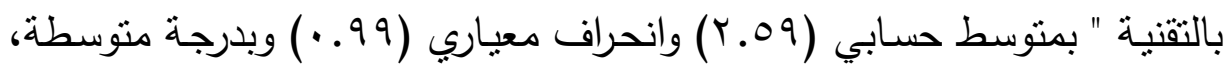
وتعـزى هـذه النتيجـة إلـى قلـة الخبـرة لـدى العـاملين في الميـدان في اسـتخدام الحاسوب فضـالً عن تبادل الخبرات بينهم لابتكار دروس غنية بالتقنية .وجاءت في الرتبة قبل الأخيرة الفقرة (7) " دمج أنواع مختلفة من البرمجيات في الأعمال

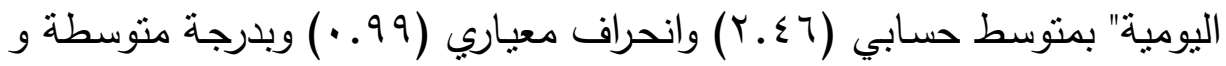
تعزى هذه النتيجة إلى قلة الاهتمام ببرامج تدريبية للحاسب فضلاً عن دمه أنواع برمجيات فيها. وجاءت في الرتبـة الأخير الفقرة (ب) " تفعبل الانترنت والمواقع

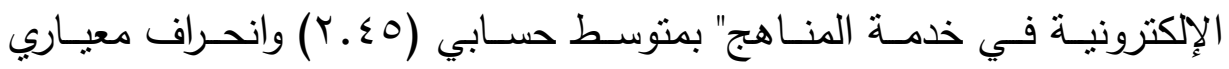
(9 9 . . ) وبدرجة متوسطة، وتعزى هذه النتيجة كما أسلفنا القول سابقاً من عدم rov 
وجود الامكانيات سواءً في هذه البرامج المقدمة واحتوائها لتدريب جميع المعلمين،

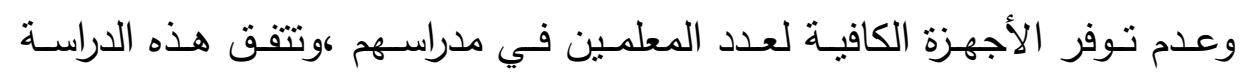

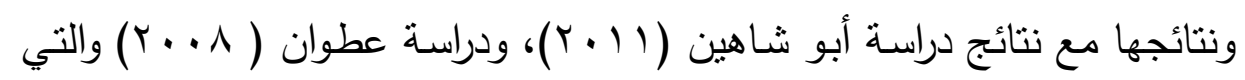
اثنارت إلى ضعف في عملية استخدام الحاسوب والبرمجيات الحديثة وتختلف مع

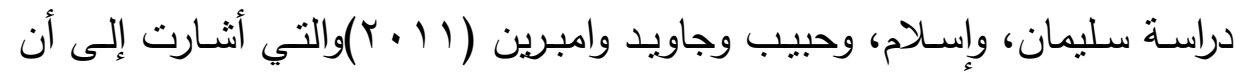

استخدام المصادرالمدمجة ذات أثز وفائدة كبيرة على أداء التلاميذ والمعلمين .

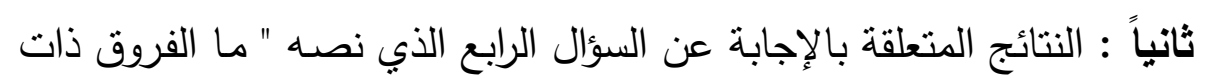
الدلالة الإحصائية عند مستوى الدلالة ( a = 0.05 ) بين وجهات نظر معلمي المرحلة الابتذائية بمدينة الطائف تجاه فاعلية البرامج التذريبية في رفع مستوى

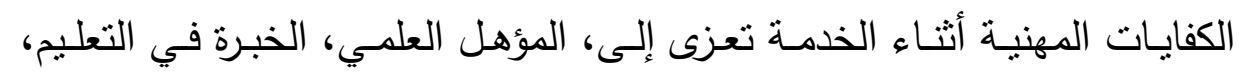

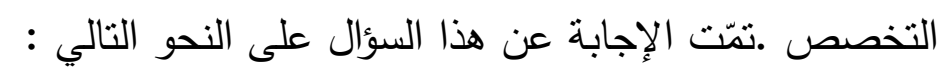
الجدول ( 9 ) ) المعيّاريـة لدور البرامج التدريبية في رفع مستوى الكفايـات المهنية لمعلمي المرحلة الابتدائية بمدينة الطائف تبعاً لمتغير المؤهل العلمي

\begin{tabular}{|c|c|c|c|c|}
\hline الانحراف المعياري & 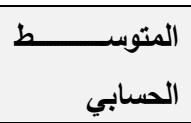 & العدد & المؤهل العملي & 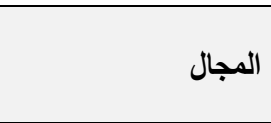 \\
\hline 0.66 & 2.79 & 149 & بكالوريوس & \multirow{4}{*}{ وتتفيذها } \\
\hline 0.60 & 2.72 & 26 & دبلوم عال & \\
\hline 0.57 & 2.65 & 36 & دراسات عليا & \\
\hline 0.63 & 2.76 & 211 & المجموع & \\
\hline 0.63 & 2.80 & 149 & بكالوريوس & \multirow{4}{*}{ الألنشطة } \\
\hline 0.50 & 2.79 & 26 & دبلوم عال & \\
\hline 0.64 & 2.59 & 36 & دراسات عليا & \\
\hline 0.62 & 2.76 & 211 & المجموع & \\
\hline 0.64 & 2.76 & 149 & بكالوريوس & \multirow{4}{*}{ الإدارة الصفية } \\
\hline 0.69 & 2.60 & 26 & دبلوم عال & \\
\hline 0.71 & 2.72 & 36 & دراسات عليا & \\
\hline 0.66 & 2.73 & 211 & المجموع & \\
\hline 0.77 & 2.54 & 149 & بكالوريوس & استخدام الحاسوب \\
\hline
\end{tabular}

\section{Doi: $10.12816 / 0052740$}




\begin{tabular}{|c|c|c|c|c|}
\hline 0.69 & 2.63 & 26 & دبلوم عال & \\
\hline 0.71 & 2.53 & 36 & دراسات عليا & \\
\hline 0.75 & 2.55 & 211 & المجموع & \\
\hline 0.68 & 2.78 & 149 & بكالوريوس & \multirow{4}{*}{ التقويم } \\
\hline 0.68 & 2.74 & 26 & دبلوم عال & \\
\hline 0.72 & 2.55 & 36 & دراسات عليا & \\
\hline 0.69 & 2.74 & 211 & المجموع & \\
\hline 0.67 & 2.73 & 149 & بكالوريوس & \multirow{4}{*}{ الدرجة الكلية } \\
\hline 0.63 & 2.69 & 26 & دبلوم عال & \\
\hline 0.67 & 2.60 & 36 & دراسات عليا & \\
\hline 0.67 & 2.71 & 211 & المجموع & \\
\hline
\end{tabular}

يلاحظ من الجدول (9) وجود فروق ظاهربـة بين المتوسطات الحسابية لدور البـرامج التدريبيـة في رفع مسـتوى الكفايـات المهنبـة لمعلمي المرحلـة الابتدائيـة بمدينة الطائف تبعاً لمتغير المؤهل العلمي ، إذ حصلت فئة (بكالوريوس) على الدرجة الكلية على أعلى متوسط حسابي (Y.VT) وفئة (دبلوم عالي) أتت ثانياً

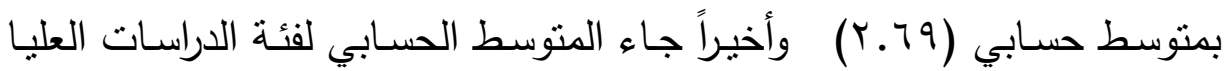

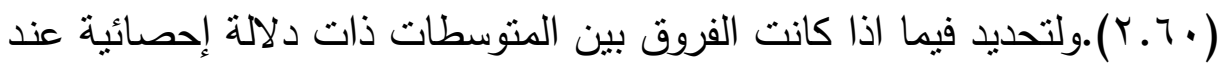

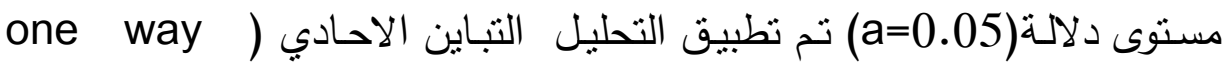
(anova الجدول ( • 1 ): تحليل التباين الأحادي لالالة الفروق في دور البرامج التدريبية في رفع مستوى الكفايات المهنية لمعلمي المرحلة الابتدائية بمدينة الطائف ثبعاً لمتغير المؤهل العلمي .

\begin{tabular}{|c|c|c|c|c|c|c|}
\hline مستوى الدلاكة & قيمة ف & المريعات & درجات & المربعات & مصدر التباين & المجال \\
\hline \multirow[t]{3}{*}{0.475} & 0.746 & 0.306 & 2 & 0.612 & بين المجموعات & التخطيط \\
\hline & & 0.410 & 208 & 85.356 & داخل المجموعات & للاروس \\
\hline & & & 210 & 85.968 & المجموع & وتتفيذها \\
\hline \multirow[t]{3}{*}{0.182} & 1.719 & 0.665 & 2 & 1.329 & بين المجموعات & الوسائل \\
\hline & & 0.387 & 208 & 80.433 & داخل المجموعات & والأساليب \\
\hline & & & 210 & 81.762 & المجموع & والأنشطة \\
\hline
\end{tabular}


دور البرامج التريبية في رفع مستوى الكفايات المهنية أ. مطلق بن سعد أحمد البرلق .

\begin{tabular}{|r|r|r|r|r|r|r|}
\hline & & & & & & \\
\cline { 1 - 5 } \\
\hline
\end{tabular}

تنير النتائج في الجدول (· (1) :

عدم وجـود فروق ذات دلالـة إحصـائية عند مسـتوى ( a=0.05 ) في دور

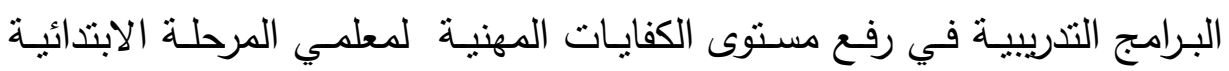
بمدينة الطائف تبعاً لمتغير المؤهل العلمي، وذلك استتاداً إلى قيمة ف المحسوبة

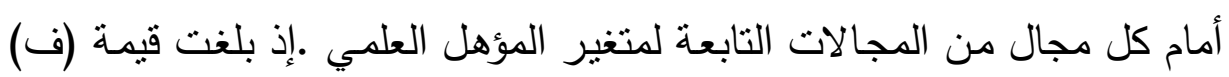

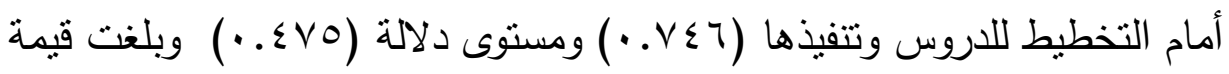

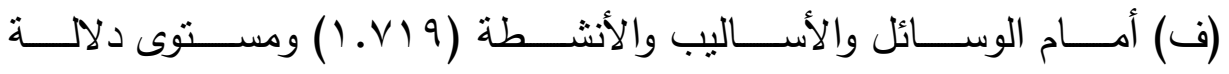

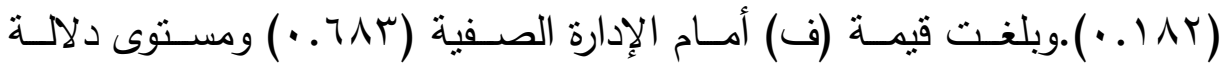

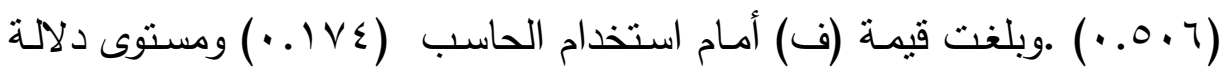

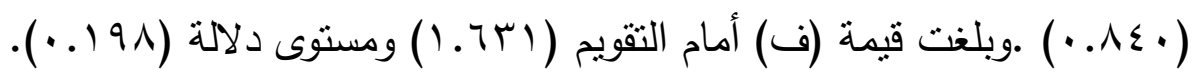

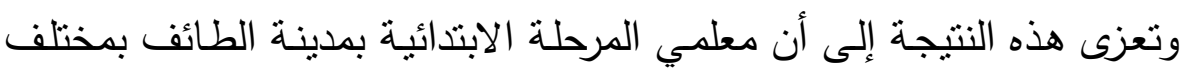

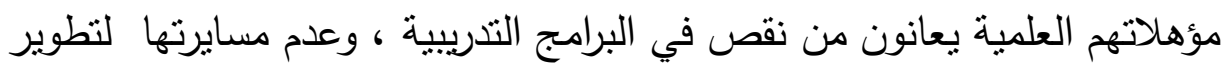

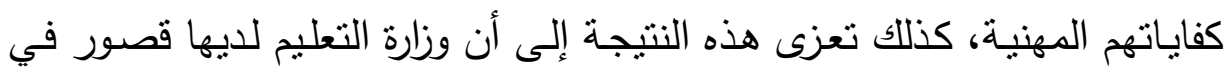
التخطيط لاحتواء أعداد المعلمين المتدربين داخل هذه البرامج، لذلك لم تظهر التهر

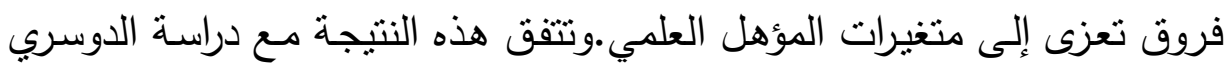

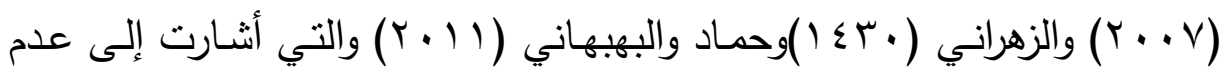

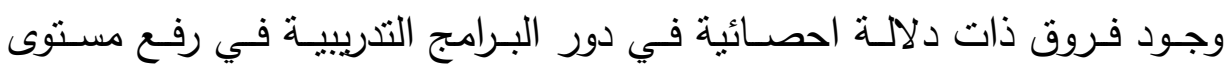


الكفايات المهنية للمعلمين، تبعاً لمتغير المؤهل العلمي.وتختلف مع نتائج دراسة

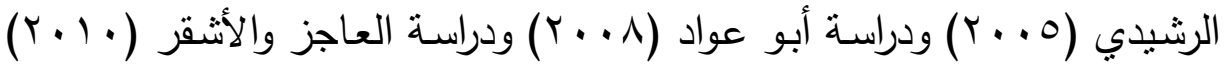
والتي أنثـارت إلى وجـود فروق ذات دلالـة احصـائية في دور البرامج التدربييـة للمعلمين

\section{الجدول (1 11 ): للدور البرامج التدريبيـة في رفـع مستوى الكفايـات المهنيـة} لمعلمي المرحلة الابتدائية بمدينة الطائف، تبعاً لمتغير سنوات الخبرة في التعليم

\begin{tabular}{|c|c|c|c|c|}
\hline المعياري & الحسابي المتوسـط & العدد & سنوات الخبرة & المجال \\
\hline 0.62 & 2.83 & 29 & أقل من 5 سنوات & \multirow{4}{*}{ التخطيط لللدوس وتتفيذها } \\
\hline 0.55 & 2.67 & 53 & 5 أقل من 10سنوات & \\
\hline 0.67 & 2.78 & 129 & 10سنوات فأكثر & \\
\hline 0.63 & 2.76 & 211 & المجموع & \\
\hline 0.67 & 2.74 & 29 & أقل من 5 سنوات & \multirow{4}{*}{ والأنشطة وبيئة التُعلمّم } \\
\hline 0.56 & 2.77 & 53 & 5 أقل من 10سنوات & \\
\hline 0.64 & 2.77 & 129 & 10سنوات فأكثر & \\
\hline 0.62 & 2.76 & 211 & 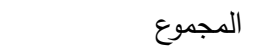 & \\
\hline 0.61 & 2.81 & 29 & أقل من 5 سنوات & \multirow{4}{*}{ الإدارة الصفية } \\
\hline 0.70 & 2.68 & 53 & 5 أقل من 10سنوات & \\
\hline 0.65 & 2.74 & 129 & 10 1سنوات فأكثر & \\
\hline 0.65 & 2.74 & 211 & 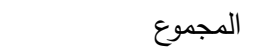 & \\
\hline 0.72 & 2.58 & 29 & أقل من 5 سنوات & \multirow{4}{*}{ استخدام الحاسب } \\
\hline 0.74 & 2.56 & 53 & 5 أقل من 10سنوات & \\
\hline 0.76 & 2.54 & 129 & 10 1سنوات فأكثر & \\
\hline 0.75 & 2.55 & 211 & المجموع & \\
\hline 0.71 & 2.74 & 29 & أقل من 5 سنوات & \multirow{4}{*}{ 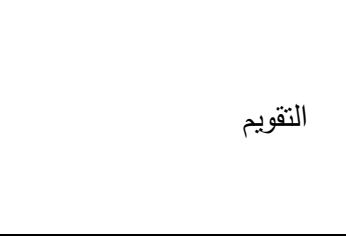 } \\
\hline 0.62 & 2.82 & 53 & 5 أقل من 10سنوات & \\
\hline 0.71 & 2.70 & 129 & 10سنوات فأكثر & \\
\hline 0.69 & 2.74 & 211 & المجموع & \\
\hline 0.66 & 2.74 & 29 & أقل من 5 سنوات & \multirow{4}{*}{ الدرجة الكلية } \\
\hline 0.63 & 2.70 & 53 & 5 أقل من 10سنوات & \\
\hline 0.68 & 2.70 & 129 & 10سنوات فأكثر & \\
\hline 0.66 & 2.71 & 211 & المجموع & \\
\hline
\end{tabular}


يلاحظ من الجدول (1) وجود فروق ظاهرية بين المتوسطات الحسابية لدور البرامج التدريبية في رفع مستوى الكفيات المهنية لمعلمي المرحلة الابتدائية بمدينة

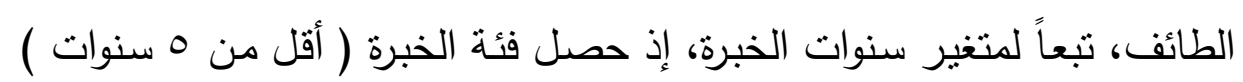

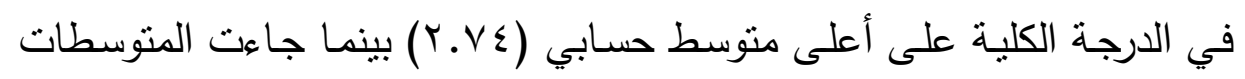

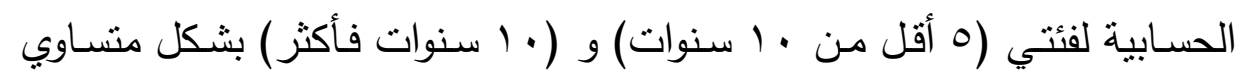
ولتحديد فيما إذا كانت الفروق بين المتوسطات ذات دلالـة إحصائية (ب.V.)

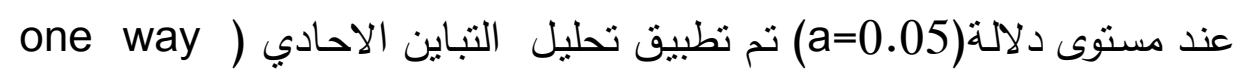
(anova جدول (r I ) : نتائج تحليل التباين

\begin{tabular}{|c|c|c|c|c|c|c|}
\hline مستوى الدلالة & قيمة ف & متوسط & لرجات & المربعات & مصدر & المجال \\
\hline \multirow[t]{3}{*}{0.440} & 0.823 & 0.338 & 2 & 0.676 & المجموعات & \multirow{3}{*}{ 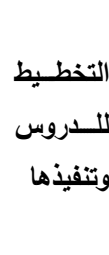 } \\
\hline & & 0.410 & 208 & 85.293 & داخجموعات ل & \\
\hline & & & 210 & 85.968 & المجموع & \\
\hline \multirow[t]{3}{*}{0.978} & 0.023 & 0.009 & 2 & 0.018 & المجموعات & \multirow{3}{*}{ والألأسياليبـة } \\
\hline & & 0.393 & 208 & 81.744 & دالمجموعاتل & \\
\hline & & & 210 & 81.762 & المجموع & \\
\hline \multirow[t]{3}{*}{0.705} & 0350 & 0.155 & 2 & 0.309 & المجموعات & \multirow{3}{*}{ الصفية } \\
\hline & & 0.442 & 208 & 91.939 & دالمجموعات لــل & \\
\hline & & & 210 & 92.249 & المجموع & \\
\hline \multirow[t]{3}{*}{0.948} & 0.053 & 0.031 & 2 & 0.061 & المجموعات & \multirow{3}{*}{ الحاسب } \\
\hline & & 0.575 & 208 & 119.540 & دالمجموعات لــل & \\
\hline & & & 210 & 119.601 & المجموع & \\
\hline 0.571 & 0.561 & 0.270 & 2 & 0.539 & بــــــــن & التقويم \\
\hline
\end{tabular}




\begin{tabular}{|c|c|c|c|c|c|}
\hline & & & & & المجموعات \\
\hline & & 0.480 & 208 & 99.893 & المجموعات لـــل \\
\hline & & & 210 & 100.432 & المجموع \\
\hline
\end{tabular}

تشير النتائج في الجدول (Y Y) عدم وجود فروق ذات دلالـة إحصـائية عند

مستوى ( a=0.05 ) في دور البرامج التدريبية في رفع مستوى الكفايات المهنية

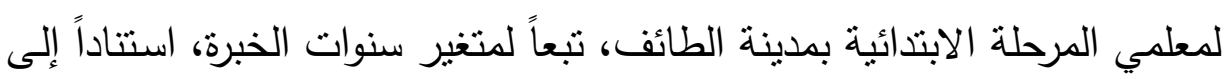
قيمة ف المحسوبة ومستوى الدلالة أمسام كل مجال من المجالات التابعة لمتغير سنوات الخبرة • إذ بلغت قيمة (ف) أمسام التخطيط للدروس وتتفيذها (سYA.. ) ومستوى دلالـة ( • ع . • ) وبلغت قيمـة (ف) أمسام الوسـئل والأسـاليب والأنثطة

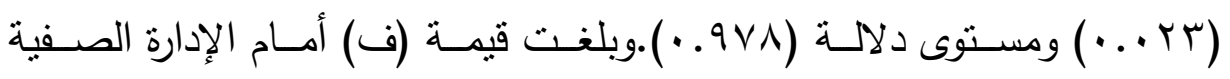

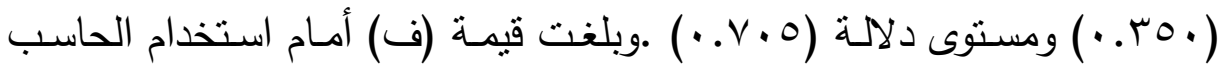

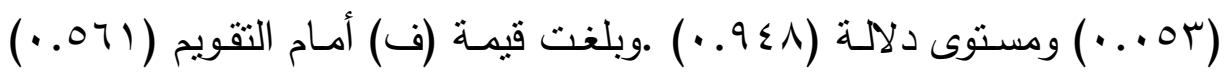
ومستوى دلالـة ( ( ) . . .وتعزى هذه النتيجة إلى أن القائمين على إعداد هذه البرامج التدريبية يهملون هذا المتغير أثتاء إعداد هذه البرامج التدربيية، ولا تفرق بين المعلم الخبير، والمعلم المستجد الذي دائما مـا يكون في حاجة إلى تطوير حتى يمتلك المهارات اللازمة للمواقف التعليمية.

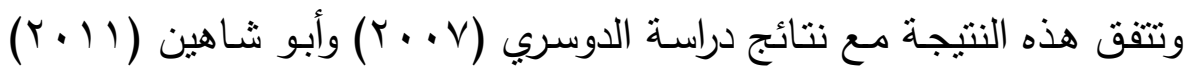
والتي أثارت إلى عدم وجود فروق ذات دلالة إحصائية في دور البرامج التدريبية في رفع مستوى الكفايات المهنية لمتغير سنوات الخبرة ، وتختلف مع نتائج دراسـة

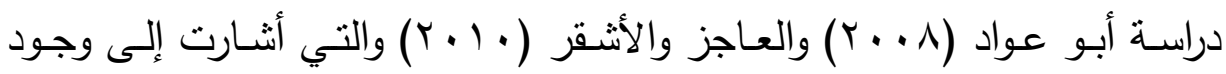
فروق ذات دلالـة إحصـائية في دور البرامج التدريبيـة في رفع مسـتوى الكفايـات المهينة للمعلمين لمتغير سنوات الخبرة. جدول (r I): ثم حساب المتوسطات الحسابية والانحراقات المعيارية لدور البرامج التديبية في رفع مستوى الكفايات المهنية لمعلمي المرحلة الابتدائية بمدينة الطائف، تبعاً لمتغيز التخصص 
دور البرامج التدريبية في رفع مستوى الكفايات المهنية أ. مطلق بن سعد أحمد البرلق .

\begin{tabular}{|c|c|c|c|c|}
\hline الانحراف & الحسابي & العدد & التخصص & المجال \\
\hline 0.65 & 2.81 & 82 & تخصصات أخرى & \multirow{4}{*}{ |التخطيـيط للــدروس } \\
\hline 0.64 & 2.77 & 72 & تخصص عربي & \\
\hline 0.61 & 2.67 & 57 & تخصص دين & \\
\hline 0.63 & 2.76 & 211 & الدجموع & \\
\hline 0.61 & 2.77 & 82 & تخصصات أخرى & \multirow{4}{*}{ 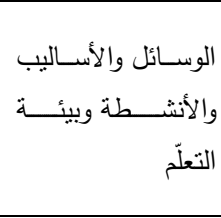 } \\
\hline 0.64 & 2.76 & 72 & تخصص عربي & \\
\hline 0.61 & 2.76 & 57 & تخصص دين & \\
\hline 0.62 & 2.76 & 211 & المجموع & \\
\hline 0.69 & 2.77 & 82 & تخصصات أخرى & \multirow{4}{*}{ الإدارة الصفية } \\
\hline 0.65 & 2.79 & 72 & تخصص عربي & \\
\hline 0.62 & 2.61 & 57 & تخصص دين & \\
\hline 0.66 & 2.73 & 211 & المجموع & \\
\hline 0.77 & 2.35 & 82 & تخصصات أخرى & \multirow{4}{*}{ استخدام الحاسب } \\
\hline 0.80 & 2.68 & 72 & تخصص عربي & \\
\hline 0.59 & 2.67 & 57 & تخصص دين & \\
\hline 0.75 & 2.55 & 211 & المجموع & \\
\hline 0.70 & 2.76 & 82 & تخصصات أخرى & \multirow{4}{*}{ التقويم } \\
\hline 0.74 & 2.77 & 72 & تخصص عربي & \\
\hline 0.60 & 2.66 & 57 & تخصص دين & \\
\hline 0.69 & 2.74 & 211 & المجموع & \\
\hline 0.68 & 2.69 & 82 & تخصصات أخرى & \multirow{4}{*}{ الدرجة الكلية } \\
\hline 0.69 & 2.75 & 72 & تخصص عربي & \\
\hline 0.60 & 2.67 & 57 & تخصص دين & \\
\hline 0.67 & 2.70 & 211 & المجموع & \\
\hline
\end{tabular}

يلاحظ من الجدول (T I) وجود فروق ظاهربية بين المتوسطات الحسابية لدور البرامج التدربية في رفع مستوى الكفيات المهنية لمعلمي المرحلة الابتدائية بمدينة الطائف، تبعاً لمتغير التخصص. إذ حصلت فئة تخصص ( عربي ) في الدرجة الكلية على أعلى متوسط حسابي ( Y.VO ) وحصلت فئة تخصص (أخرى)على متوسط حسابي (99.7)وأخيراً جاء المتوسط الحسابي لفئة تخصص دين إذ بلغن (Y.TV) ( ولتحديد فيمـا إذا كانـت الفروق بين المتوسطات ذات دلالـة إحصـائية one way ( عند مستوى دلالة (a=0.05) تم تطبيق التحليل التباين الاحادي 
(anova

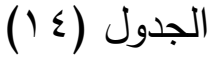

\begin{tabular}{|c|c|c|c|c|c|c|}
\hline مستوى & قيمة ف & متوسط المربعات & لدرجةّ & المربعات & مصدر التباين & المجال \\
\hline \multirow[t]{3}{*}{0.440} & 0.825 & 0.338 & 2 & 0.676 & بين المجموعات & \multirow{3}{*}{ لتنفطيذها للدروس } \\
\hline & & 0.410 & 208 & 85.292 & داخل المجموعات & \\
\hline & & & 210 & 85.968 & المجموع & \\
\hline \multirow[t]{3}{*}{0.999} & 0.001 & 0.665 & 2 & 0.001 & بين المجموعات & \multirow{3}{*}{ 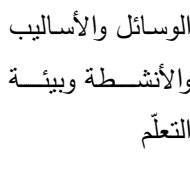 } \\
\hline & & 0.387 & 208 & 81.761 & داخل المجموعات & \\
\hline & & & 210 & 81.762 & المجموع & \\
\hline \multirow[t]{3}{*}{0.245} & 1.415 & 0.619 & 2 & 1.238 & بين المجموعات & \multirow{3}{*}{ الإدارة الصفية } \\
\hline & & 0.438 & 208 & 91.011 & داخل المجموعات & \\
\hline & & & 210 & 92.249 & المجموع & \\
\hline \multirow[t]{3}{*}{0.010} & 4.659 & 2.564 & 2 & 5.129 & بين المجموعات & \multirow{3}{*}{ استخدام الحاسب } \\
\hline & & 0.550 & 208 & 114.472 & داخل المجموعات & \\
\hline & & & 210 & 119.601 & المجموع & \\
\hline \multirow[t]{3}{*}{0.613} & 0.491 & 0.236 & 2 & 0.472 & بين المجموعات & \multirow{3}{*}{ التقويم } \\
\hline & & 0.481 & 208 & 99.960 & داخل المجموعات & \\
\hline & & & 210 & 100.432 & المجموع & \\
\hline
\end{tabular}

تشـير النتائج في الجدول (ع () إلى وجـود فروق ذات دلالـة إحصـائية عند

مستوى( a=0.05 ) في دور البرامج التدربيبة في رفع مستوى الكفايات المهنية لمعلمي المرحلـة الابتذائيـة بمدينـة الطـائف، تبعـاً لمتغيـر التخصص في مجـال (استخدام الحاسوب) استتاداً إلى قيمـة ف المحسوبة إذ بلغت (709. ؟ ) بمستوى دلالة ( • ( . • ) وهذه النتيجة تنتفق مسع نتائج دراسـة الدوسري التي اشـارات إلى وجود فروق ذات دلالة إحصائية تعزى إلى متغير التخصص .أما بقية المجالات فلم تظهر فيها فروق، إذ كانت قيمة ف ومستوى الدلالة غير دالة إحصائياً .وقد 
دور البرامج التدريبية في رفع مستوى الكفايات المهنية أ. مطلق بن سعد أحمد البرلق .

تعزى هذه النتيجـة إلى أن ( اسـتخدام الحاسوب) مهم للدى بعض التخصصـات العلمية مما أوجد الفرق لديها عن باقي التخصصات الأخرى. 
في ضوء النتائج التي توصلت إليها الدراسة فإن الباحث يوصي بالآتي :

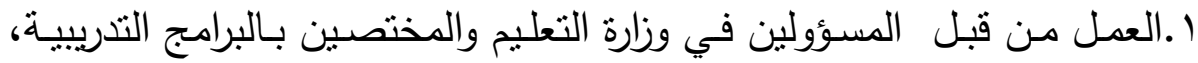

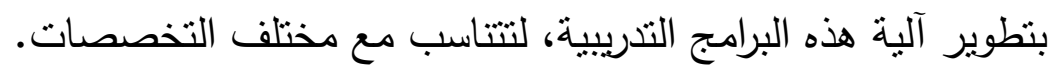
r.إدخال عامل الجذب والنتويق والإثارة من قبل القائمين على إعداد البرامج

$$
\text { التدربيية. }
$$

r.ربط هذه البرامج التدريبية بعملية ترفيع المعلم أو حصوله على درجة سنوية كزيادة على راتبه. ع .أن يكون لاي المعلمين الرغبة وبخاصة الجدد منهم على حضور هذه هذه البرامج

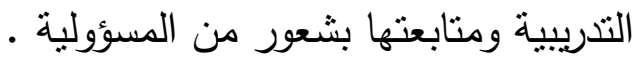

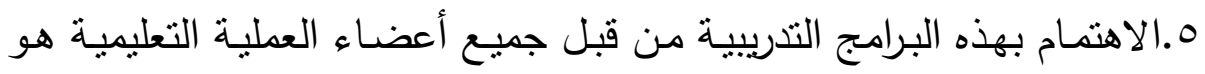

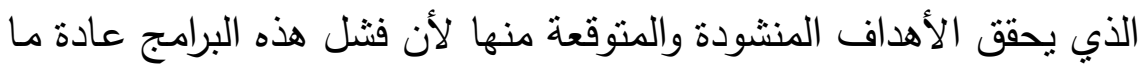
يكون نتيجة لعدم اهتمام أعضاء العملية التعليمية بها بالثكل المطلوب.

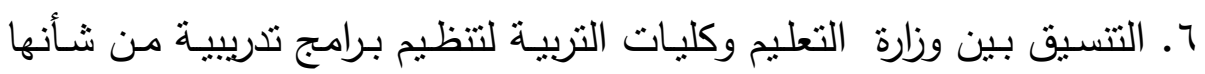
تلبية احتياجات المعلمين أثثاء المهنة . V.يجب على القائمين بإعداد هذه البرامج التدريبية الأخذ في الاعتبار مراعاة

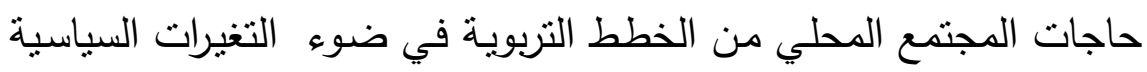
والاجتماعية والثقافية والاقتصادية الحاصلة. ^.اختيار الأوقات المناسبة لتنفيذ البرامج التدريبية للمعلمين في مختلف مراحلهم التعليمية . 9.عقد البرامج التدريبية وتتفيذها للمعلمين علي شكل برامج مكثفة قصيرة المدى

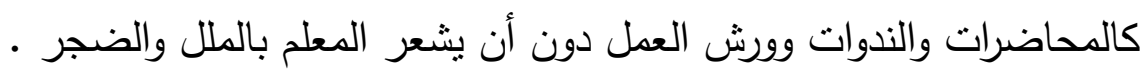




\section{المقترحات :}

أجراء دراسـة تتتـاول " فاعليـة البـرامج التدريبيـة في رفع مسـتوى الكفايـات

المهنية لمعلمات المرحلة الابتدائية بمدينة الطائف من وجهة نظرهن ".

r.إجراء دراسـة تتـاول " فاعلية البرامج التدربيية في رفع مستوى الكفايـات

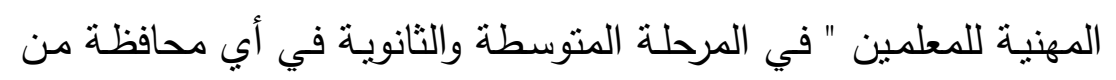

محافظات المملكة.

س.بحث أثر البرامج التدريبية التي يتلقاها المعلمون وهل سـاهمت في تقدم العملية التعليمبة، ومدى استفادة التلاميذ من معلمهم.

ع .إعداد البرامج التدربية التي تعتمد على استراتيجيات التعلم الحديث كالتعلم

النشط، والتعلم عن طريق وسـئل التكنولوجيا الحديثة ومدى الاستفادة

- من 


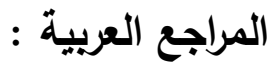

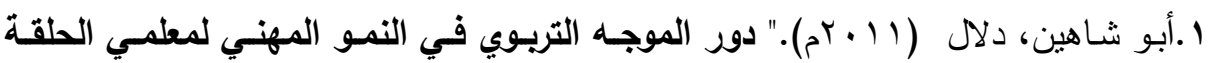
الأولى مـن مرحلة التعليم الأساسي"، دراسـة ميدانية لآراء المعلمين في محافظة

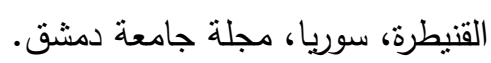

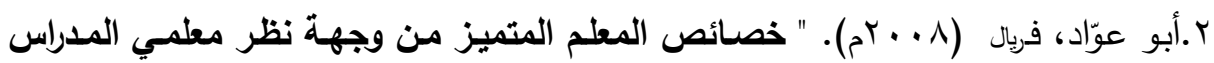

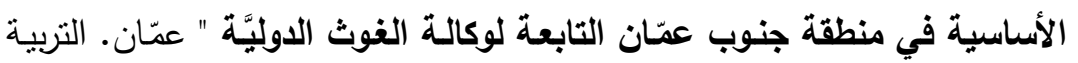
العلمَّية رؤى مستقبلية ج الطط ا مكتبة المجتمع العربي للنشر والتوزيع.

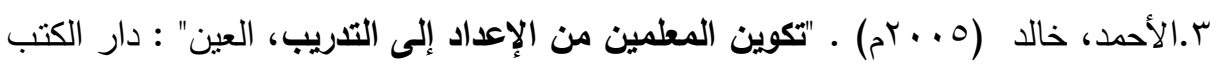

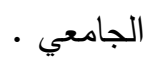

ـ .إثراقة، أحمد (7 . . rم). "مؤسسات وصيخ إعداد معلّم الكبار في السودان، دراسـة حالة "

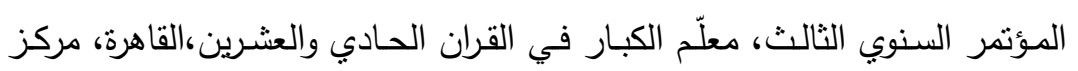
تعليم الكبار بجامعة عين شمس.

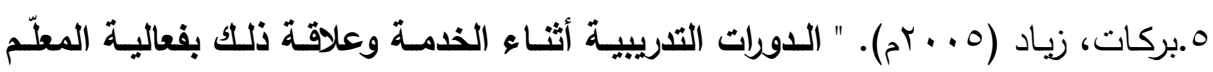

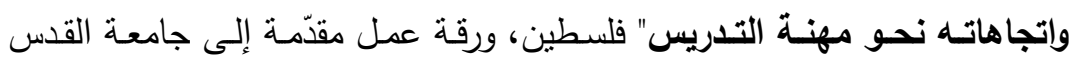

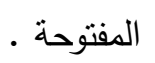

7.بطاينـة، أسـامة (ع . . rم). " تقـويم الكفايـات التعليميـة لمعلمـي الأطفـال ذوي الحاجـات

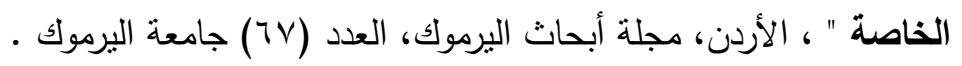

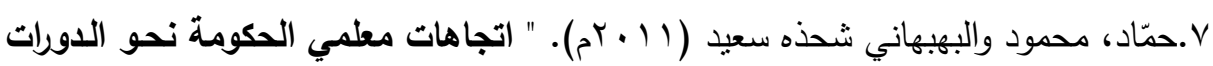

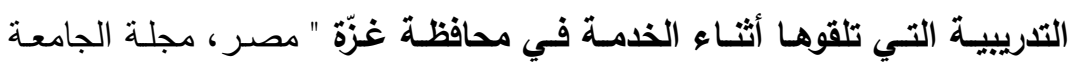

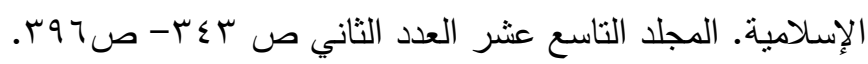

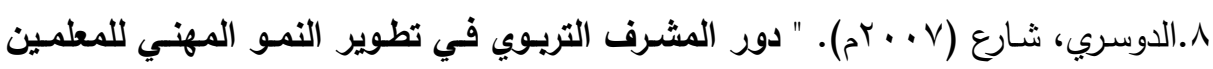

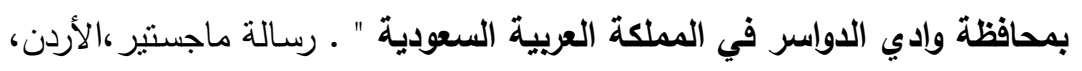

$$
\text { جامعة اليرموك. }
$$

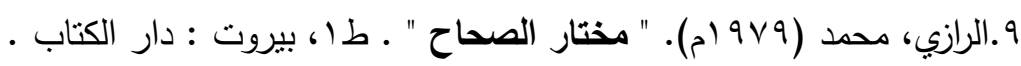

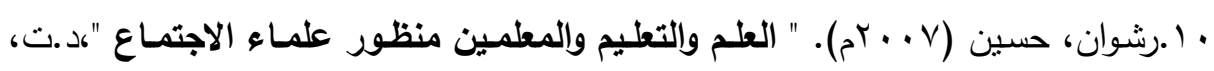

$$
\text { مؤسسة شباب الجامعة. }
$$

ا الرشيدي، فلاح (0 . . rم). " كفايات معلمي الطلبة المتفوقين في دولة الكويت "، رسالة

$$
\text { ماجستير ، د.ت }
$$


r ا .الزهراني ، بندر (اس؟ اهـ) "دور الدورات التدريبية في تطوير المهارات التدريسية لمعلمي التربية القنية من وجهة نظرهم "،رسالة ماجستير ، مكة ، جامعة أم القرى.

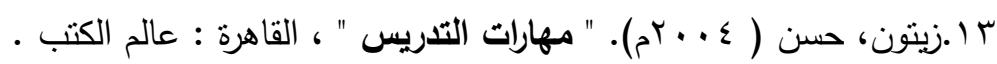

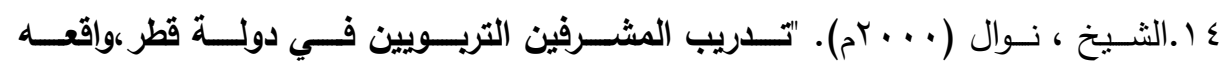
ومشكلاته".قطر ،مجلة التربية، العدد (Y Y I).

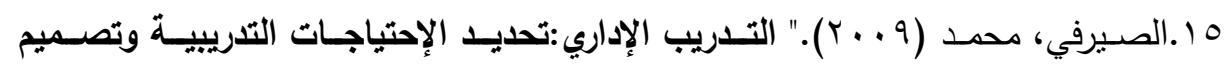
البرامج التدريبية،مصر ،دار المناهج للنشر والتوزيع.

7 ا .العاجز ، فؤاد ( ؟ . . rم). " تقويم دورات تدريب معلمي المرحلة الثانويـة أثناء الخدمـة

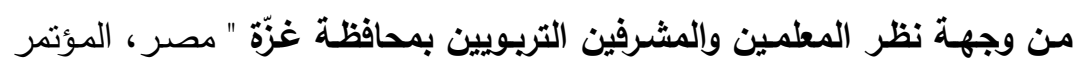
العلمي السادس عشر للجمعية المصرية للمناهج وطرق التدريس ( تكوين المعلّم )

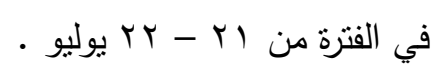

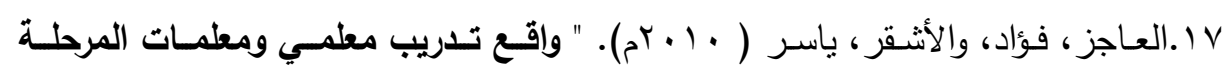

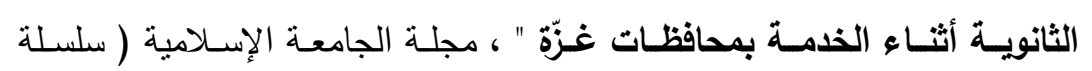

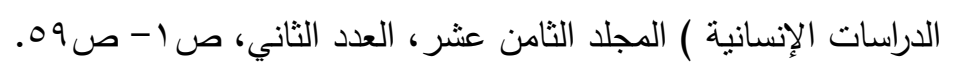

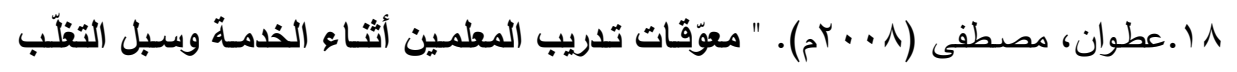

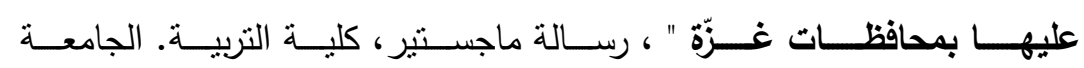
الإسلامية،فلسطين، غزّة.

9 1.مجمع اللغة العربية ( ـ99 (م). " المعجم الوجيز " ، مصر ، وزارة التربية والتعليم. • . .مجمع اللغة العربية (ع . . rم). " المعجم الوسيط" ،مصر ، مكتبة الثروق الدولية.

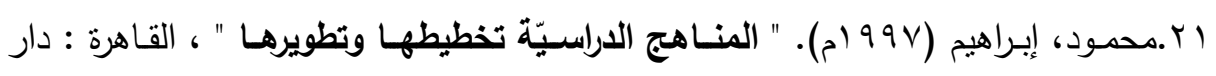
المعرفة الجامعية.

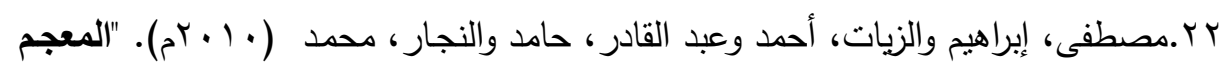

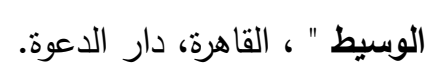

بr.المطر ، عبد الحكيم بـن جواد (ع . . rم). " الكفايـات المهنيـة لمعلمـي التربيـة البدنيـة

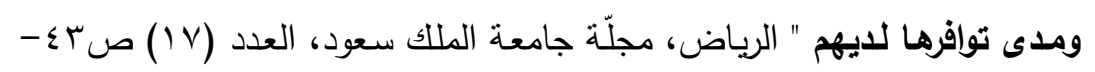

$.7 V$

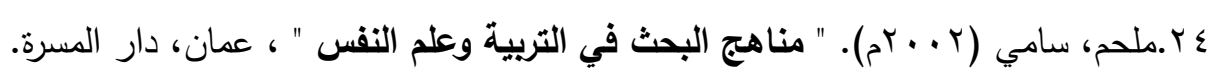

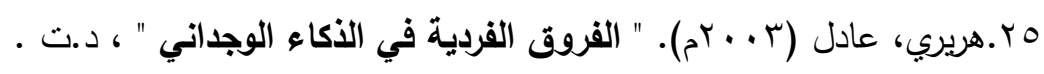

\section{Doi: 10.12816/0052740}




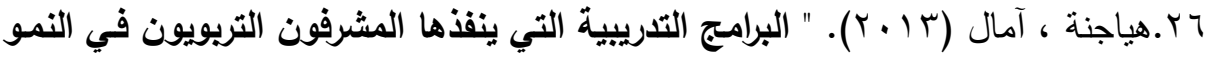

المهني للمعلمين أثناء الخدمة" رسالة ماجستير ، الأردن، جامعة عمّان.

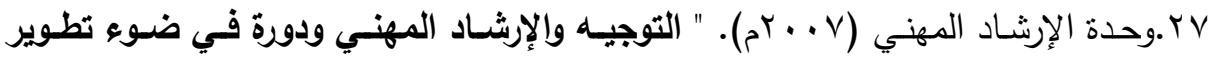

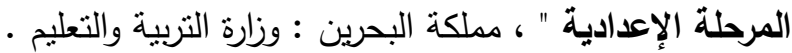

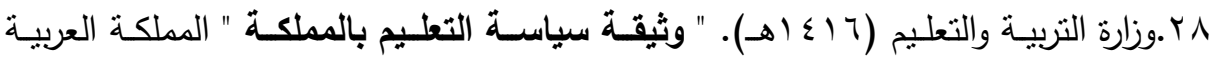

السعودية، الرياض.

المراجع الأجنبية

1.A.C.Kgoz Firat (2005) Astuday on teachers characteristics and their effects on students attitudes, retrieved 17.apr.2007 erciyes ahacttepe. Edu.tr.

2.Haslinda, A, (2009) "the effectiveness of training in the public service". American journal; of scientific research, vol.6,39-51.

3.Joseph, s, \& ping - lung ( 2004), " employee training and human capital in Taiwan", journal of world business, vol.39,362-376.

4.Kapusuzoglu, S, \& Balaban, c., (2010). Roles of primary education supervisors in training candidat teachers on job, European, journal of scientific research, vol.42 no.1,pp.114-132.

5.Kilber, h. (2002) educational competence among history teacher in nevade public school. The educational journal, 13, 145-155.

6.Rudolph, A.A (2002) " the effects of role - play as amethod in classroom management courses on in-service teacher's attitudes and effectiveness". ERIC, No. AAG3055344.

7.Suleman, Q, Aslam, H, Habib, M, Javed, T\& umbrin, S (2001) Evaluative study of the effectiveness of teaching performance of in-service promoted secondary school teacher in Khyber. 
دور البرامج التدريبية في رفع مستوى الكفايات المهنية أ. مطلق بن سعد أحمد البرلق . 